Portland State University

PDXScholar

$10-1-2020$

\title{
Moonlit Nights and Seasons of Romance: Yosano Akiko's Use of the Moon in Tangled Hair
}

Teppei Fukuda

Portland State University

Follow this and additional works at: https://pdxscholar.library.pdx.edu/open_access_etds

Part of the Japanese Studies Commons

Let us know how access to this document benefits you.

\section{Recommended Citation}

Fukuda, Teppei, "Moonlit Nights and Seasons of Romance: Yosano Akiko's Use of the Moon in Tangled Hair" (2020). Dissertations and Theses. Paper 5580.

https://doi.org/10.15760/etd.7452

This Thesis is brought to you for free and open access. It has been accepted for inclusion in Dissertations and Theses by an authorized administrator of PDXScholar. Please contact us if we can make this document more accessible: pdxscholar@pdx.edu. 
Moonlit Nights and Seasons of Romance: Yosano

Akiko's Use of the Moon in Tangled Hair

by

Teppei Fukuda

A thesis submitted in partial fulfillment of the requirements for the degree of

\author{
Master of Ars \\ in \\ Japanese
}

Thesis Committee:

Jon Holt, Chair

Laurence Kominz

Suwako Watanabe

Portland State University

2020 
(C) 2020 Teppei Fukuda 


\begin{abstract}
Ever since they opened their country to the world in the late nineteenth century, the Japanese experienced drastic changes in many aspects. They rapidly absorbed Western culture with their desperate hope to modernize their country in politics, the sciences, and art. Literature was not an exception. Yosano Akiko (1878-1942), who is well known as a pivotal poet of Japanese Romanticism, absorbed this new modern sense of self and individuality and advocated the poetic expression of one's private and personal emotions.

In premodern Japan, poets had traditionally expressed their feelings through a set, limited range of classical landscapes and natural objects, which served as communal symbols Japanese poets shared across centuries. The seasons greatly occupied the attention of poets for more than a thousand years. The moon also is an important element in Japanese poetry with a set range of conventionalized poetic associations. However, by the turn of twentieth century, Yosano Akiko absorbed from the West the inspiration to express her personal feelings with her own invented moonlit landscapes, particularly ones set during spring and summer evenings. This thesis investigates what changes she made to the poetic conventions of the moon and the seasons in traditional thirty-one-syllable poetry.
\end{abstract}




\section{Acknowledgements}

Firstly, I would like to express my sincerest gratitude to my thesis advisor, Professor Jon Holt, for his warm and continuous advice and support. Without his guidance and insight, I could not have completed this project. I must also thank Professor Laurence Kominz and Professor Suwako Watanabe for kindly being part of the thesis committee. My sincere thanks also go to another faculty member of the Japanese department, Professor Karen Curtin; my previous and current colleagues in the Japanese department; the staff of the Department of World Languages and Literatures; my dearest friends I met here in Portland through music and the study of language and literature; my friends in Japan; the Wishers, my American family who have always been supportive; also people in International Special Program office and ANDEO, with which I had very precious working experience.

I would also like to express my special thanks to two of my dearest friends, Olivia Hughes and Bobby Lukas, who have been helping me to get through this challenging period of the pandemic. Without their warm support and compassion, I could not even continue my study.

Finally, I would like to thank my family, Minako, Toshirō, and Atsuko for their continuous encouragement and warmest smiles. 


\section{Table of Contents}

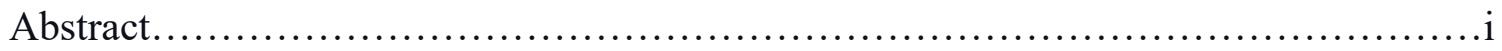

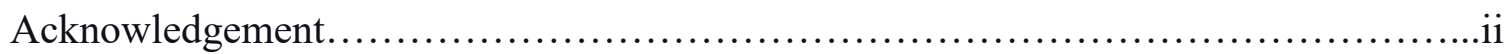

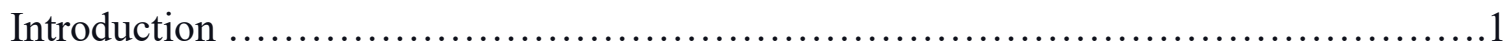

Chapter I: The Spring Moon in Tangled Hair ...................................... 9

The Modern Girl's Pale Moon

The Joy of Love on Moonlit Nights

The Beginning of Akiko's Romantic Spring Moon

Chapter II: The Summer Moon: Yosano Akiko’s True Feeling and Her Romantic Sin...33 Creation of New Symbols

The Landscapes of Summer

The Summer Moon Poems in Tangled Hair

Buson's Moon and Akiko's Moon

Symbolism and Japanese Poetry

The Subjectivity and New Emotion

Romantic Sin

Poems of Sin Under the Summer Moon

Realistic Moons and Romantic Moons

Conclusion.............................................................. 79

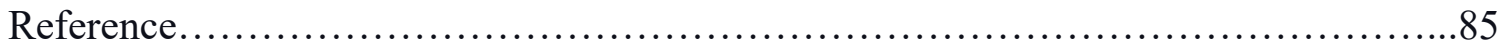




\section{Introduction}

Yosano Akiko (1878-1942), one of the most important poets of Japan's modern period (1868-1945), gained notoriety for her radical expressions of love and passion of romance in her first collection of tanka (modern waka or 31-syllable poetry) called Tangled Hair (Midaregami 1901). Her poetry was considered very sensational and innovative for its time. Not only Akiko's tanka itself, but her use of the moon was also something new and explored new meanings for the moon in this traditional poetry genre.

In waka (traditional 31-syllable poetry) the four seasons play a pivotal role and the moon is considered a classic seasonal word for autumn. A significant function of the moon in the waka tradition is as an elicitor of melancholic thought. In addition to melancholy, there are numerous functions of the moon in Japanese poetry to name here, for example, a symbol of nostalgia, romantic longing, an icon of Buddhist enlightenment, political power, reflection of someone's face or oneself, and so forth.

However, in Tangled Hair, the pioneer of the Japanese Romanticism, Yosano Akiko, changed the old meanings of the spring and summer moon and made them new by converting them into emblems of happiness and passion, frequently caused by romantic feelings. She preferred the moon on spring evenings to best capture the flowery excitement of young romance and the summer moon to represent invigorating romantic 
passion, which according to her, is something everything (banbutsu) in the universe should feel in those hot months.

Akiko was not only a modern poet but also a poet who could skillfully handle traditional topics. She grew up reading classical Japanese literature, and in her mid-later career, she devoted herself as an educator of Japanese literature with her husband, Yosano Tekkan (1873-1935). She started giving lectures on Tale of Genji (Genji monogatari, ca 1000), which is the oldest novel in Japan—and possibly in world literature, written by Murasaki Shikibu (978-1016) at her home in 1909. At the same time, Tekkan was teaching the Man'yōsh traditional poetry. Akiko also published modern Japanese translations Japanese classical literary works, such as Tale of Genji, a poem anthology of Izumi Shikibu (976-1030), and Essays in Idleness (Tsurezuregusa, ca. 1331) and so on. In other words, both she and her husband were fluent in traditional Japanese literary aesthetics. Moreover, in 1921, she became a co-founder of Japan's first co-educational school called Bunka Gakuin (lit. culture school), the goal of which was enlightening Japanese people with art and literature. Akiko became the head of the Department of Literature with Tekkan. The husband and wife duo were prominent educators and promoters of Japanese classic literature.

On the other hand, it is also a well-known fact that she greatly admired other, later pioneers of Japanese poetry, such as the Edo period (1600-1868) haikai poet, Yosa Buson (1716-1784). She also greatly favored her contemporary, the great early Meiji-period Japanese Romantic—who became a Realist later—Shimazaki Tōson (1872-1943). As one 
can imagine from her brilliant career as an educator of Japanese literature, readers recognize Akiko's skillful mixture of modern literary sensibility and rigorous classical acumen.

When one thinks of the most significant and typical images of traditional Japanese poetry, of course one thinks of cherry blossoms (sakura) and autumn leaves (momiji) but also the moon (tsuki). Flower and bird, wind and moon (kachō fügetsu) have traditionally been pivotal elements to illustrate nature and the four seasons. Haruo Shirane, the Shincho professor of Japanese Literature and Culture at Columbia University, wrote in Japan and the Culture of the Four Seasons: Nature, Literature and the Arts wrote: "The overwhelming influence of this 'flower and bird, wind and moon' (kachō fügetsu) model can be attributed to the literary and cultural impact of the imperial court" (Shirane). Since the era of Kokin wakash $\bar{u}$ (Poems of Past and Present, 905; hereafter Kokinshū), which is Japan's first imperial poetry anthology of thirty-one syllable poetry, Japanese people have often turned to the moon to express their feelings in poems, usually in this short poetic form, historically called waka but now known as tanka.

As we will see in this thesis, her expression of a romantic moon is something different from the moon traditionally written about in classical poetry. Akiko's feelings and emotions are closely associated with her romantic moons. She writes about the moon and flowers in her second book on composing of tanka poetry called Talks on Tanka (Akiko kawa 1919), which is compiled in Collected Works of Yosano Tekkan and Akiko (Tekkan Akiko Zensh $\bar{u}$ [hereafter TAZ]: 20). The moon and flowers talk to her and respond to her emotions, and sometimes even express their own emotions. She describes 
her poetic process that seems to have been fully conceived when she even began writing her Tangled Hair tanka by 1900:

My emotional state at that time was a mix of my aspirations and hopes as well as my pessimism and despair. I felt both a rich joy and a painful sorrow. I had such extravagant illusions, such warm benevolent emotions. The flowers and the moon were not cold and indifferent natural objects, but talked to me, shed tears for me, and had me to convey their emotions to people. I felt that I could share my happiness and sorrows with flowers and the moon. (TAZ 20:75-76)

Needless to say, these things were all happening in her inner world. In her internal, psychological world, her emotions resonated with flowers and the moon. Flowers and the moon expressed their own emotions by talking to her or even shedding tears with her. In other words, they shared their emotions with Akiko in her inner world. Akiko also said that the landscapes in her poems are externalizations of her inner self, the complicated mind of a modern human being. Along with feelings of seasons, the moon and flowers play pivotal roles in forming landscapes that represented her interiority.

Haga Tōru, one of the leading scholars of literary criticism, claimed that "there are an enormous number of poems about the moon, and this fact makes us think that Japanese people have been moon lovers (tsukigurui) from a long, long time ago" (Haga 90). Most of the prominent tanka (or more precisely, waka) poets, perhaps Haga's “moon lovers" (tsukigurui), often composed their thirty-one syllable lyrics about the moon, and one can easily find poems about the moon in personal waka collections of notable poets as well as in imperial anthologies. The moon has been something close to the Japanese people, not only to poets as a poetic word but even to ordinary Japanese who may never have composed a verse of poetry in their lives. 
Tsukimi (moon viewing) in autumn is a traditional annual event still enjoyed in Japan. Even now, people still get together for tsukimi and enjoy gathering to watch the moon while consuming food and drink. Haga also mentions the relationship between the moon and the Japanese. "Japanese people, who were originally an agricultural tribe that used the lunar calendar, have long loved the unlimited expressions and impressions of the moon, which change along with the combination of the seasons, weather, lunar phases, and places and have been composing poems about it as if they are a tribe of the moonlight" (Haga 94). As he says, Japanese people have always held an admiration for the moon, which both shows the transition of time in the month and reflects the changes in the four seasons. "The seasons" and the "weather" become two important forces of Japanese cultural expressions in poetry, because of the unique climate of the Japanese archipelago.

More than the moon, the four seasons play the most substantial role in Japanese poetry, where most of the poetic words allowed in classical Japanese waka poetry have a specific season, so they function as seasonal words in poems, often to fit the demands of a composition topic (dai). Even though the moon is something we can enjoy throughout the year, it is also usually associated with a specific season. And autumn is the season of the moon in Japanese poetry. Unless it is qualified with a modifier mentioning other seasons, such as the spring night moon (haru no yo no tsuki), a moon poem by default is an autumn poem. Shirane wrote that the moon came to have this function at least by the time of Kin'yōshū (Collection of Golden Leaves, 1124). The poems in Kokinshū and Shin kokin wakash $\bar{u}$ (New Poems of Past and Present, 1205) are organized primarily by the 
four seasons. Then, following the convention established by these two anthologies, majority of the imperial anthologies were organized in this way.

For example, the first two parts (books) of Kokinsh $\bar{u}$ are on spring; book three is on summer, and so forth. In other words, anthology editors treated the four seasons as the primary organizing category in these imperial waka anthologies, and this tradition continued for generations. As we can see from these facts, the sense of the four seasons is something important not only in the organization of imperial anthologies but also crucial to the thirty-one-syllable form of waka poetry itself. The imperial anthology genre is the very thing that conventionalized the moon as a seasonal word for autumn. "The association of the moon with autumn," Shirane writes, "was so strong in the imperial waka anthologies that eventually the moon came to symbolize autumn itself"' (Shirane). So the moon and autumn became a convention at least by the Medieval Period (11851600), and this sense is still vibrant even now in the Contemporary Period (1945present).

However, how does the moon function as a seasonal word in Japanese poems? Since the era of Kokinsh $\bar{u}$, the moon has functioned as something to elicit one's thoughts, often best understood as melancholy. "The full arrival of autumn in the Kokinsh $\bar{u}$ however, comes with the appearance of the light of the autumn moon in the night sky, which is described as eliciting melancholy thought" (Shirane). Another possible source of this association of the moon and melancholy feelings is Taketori Monogatari (ca 900), in which the heroine, a girl from the moon gazes at the moon and longs to return home. This function of the moon as an elicitor of melancholic feelings is something still common in Japan today. Haga mentions the fact that this aspect of the moon is found in 
contemporary Japanese culture. "The emotional reaction, which was a convention of poetry, became a shared emotional response by Japanese people, deeply rooted in the climate of Japan, and it has survived until today. This emotion is something still vibrant even in the heart of a modern girl, who wears a pair of navy blue jeans, and walks on a street in autumn in Tokyo in the 1970s" (Haga 102). Alongside its role as an elicitor of one's more profound emotions, there is another role of the moon in Japanese poetry.

In her tanka, Akiko treats this traditional topic in her own way. She uses the moonlit landscapes to externalize her feelings. Akiko's landscapes are depictions of a young girl's flowery excitement of love in the evening in spring or romantic passion on summer nights, which are not at all melancholic thought. However, more importantly, these landscapes are all representations of her true feeling and her inner self.

The sense of self was an idea derived from the West and seen as a new and modern thing to the eyes of people in Meiji (1868-1912) Japan. Although Akiko was using traditional topics — such as the moon — as pivotal elements of her landscapes, what she truly illustrated with these landscapes was new in the Meiji period. Therefore, an analysis of Yosano Akiko's moon and seasons tells us how people in the modern era, who had just encountered and started becoming influenced by the West, modified the traditional ideas of seasons that had been dominant for a thousand years in Japan. Thus, as a truly modern representative of Meiji Japan, Akiko channeled her ideas of being a modern woman through the moon in its various seasons. She used the moon to awaken others to a new sensibility of self.

Chapter One examines Akiko's spring moon and her expression of romantic feelings by focusing on what she modified from traditional poetic practice. Chapter One 
also investigates the influence of Shimazaki Tōson —-who was a very influential poet for Akiko — on Akiko's poetic spring moon. The summer moon and Akiko’s poetic approaches such as jikkan (true feeling), Akiko's symbolism, her romantic sin against old morality and the sense of self are the themes of Chapter Two. Chapter Two also examines the influence of Yosa Buson (1716-1784) — another influential poet for Akiko - as well as comparison between Akiko's moon and Masaoka Shiki's moon. I examine some of the differences and similarities between Realism and Romanticism in poetry, as they were two major literary currents of the Meiji Period. 


\section{Chapter I}

\section{The Spring Moon in Tangled Hair}

Yosano Akiko is known as a poet of modern Japan (1886-1945), and she can skillfully handle both modern and traditional topics. However, when she treats traditional themes or ideas, she often adds her own take or modifies traditional ideas in her own way. In the tradition of waka, one of the major roles of the moon is an elicitor of one's sadness, which is also associated with the season of autumn. Since the time of Kokinsh $\bar{u}$ (905), the moon has functioned as something to elicit one's thoughts, often best understood as melancholy. Shirane wrote "The full arrival of autumn in the Kokinsh $\bar{u}$ however, comes with the appearance of the light of the autumn moon in the night sky, which is described as eliciting melancholy thought" (Shirane). He also articulated that the poem below in Kokinsh $\bar{u}$ is the one that "clearly established this image's poetic essence":

木の間よりもりくる月の影見れば心づくしの秋は来にけり

(Kokinshü, no. 184, anonymous)

When I see the light of the moon leaking through the trees, I know that the heart-wrenching autumn has arrived

(Shirane)

Akiko presents traditional topics like the moon and melancholy, but she often modifies the theme and adds a new impression or twist. As a case in point, she used the moon in a sad poem in her debut tanka collection Tangled Hair; however, the moon here is not 
something that elicits one's melancholic thought. In this poem the moon is a force of nature that cares about a woman drenched in her sadness. It protects her by not casting its spotlight on her face:

月こよひいたみの眉はてらさざるに琵琶だく人の年とひますな (Yosano Akiko)

Even tonight, when the moon

does not cast light on

her eyebrows and pain,

a lady is holding a biwa ${ }^{1}$

Please, do not ask her age. ${ }^{2}$

Although the moon usually works as an elicitor of sadness, Akiko takes the moon as a thing that conceals a lady who is feeling the pain (itami) and perhaps shame of love from people by not illuminating her face. Then the poet says, "do not ask her age" to the interfering people who do not have enough etiquette to leave her alone. In other words, the moon helps her to hide from those people who do not have a sense of manners or discretion. As we can see from this example, when she works on very traditional topics or themes—-here the moon and melancholy—she often modifies these traditional figures. In this poem, she changed the moon into something that protects the lady from gossiping people. The moon will not make her melancholy worse. A Japanese poet Konno Sumi commented on this poem: "She feels more warm emotion $(j \bar{o})$ from the moon than from neighbors," who would interfere in her affairs. Konno asserts "this poem is perhaps the

\footnotetext{
${ }^{1}$ A Japanese lute.

2 Translation by myself; unless otherwise stated, all poem translations are by this author. Modifications, if made, to translations by other scholars will be noted.
} 
result of Akiko's imagination about romance in ancient Japan” (Konno). According to Konno, this poem is Akiko's wild daydream of ancient Japanese culture. Akiko indeed chose the court culture of the Heian period as a theme of her romantic poems, which express longing for the ancient Japanese court culture. So what were the romantic relationships in the Heian court culture like? What was the role of men and women in Heian romances?

In the Heian period (794-1185), aristocratic men and women lived separately, and men were the visitors, or instigators, in romantic relationships. In other words, unless a man visited the house of a woman in the evening, they could not even see each other. Because of their lifestyle, women often had to wait and long for somebody under the moonlight. The moon is something a lady watched, to which she even talked and posed questions, as she waited or was longing for somebody she loved. Indeed, in Akiko's later works - especially the ones from her later career-we can find autumn moon poems in which we can see the sense of waiting and romantic longing.

Compared to this first poem, in which she creates a somewhat traditional atmosphere, Akiko shows her modern aspect in other moon poems in Tangled Hair. In these, she did not just add her take on traditional topics, but she gave a very new and modern aspect to the moon. Her spring moon illuminates a more positive, optimistic, and flowery excitement about love in this poem from 1901.

下京や紅屋が門をくぐりたる男かはゆし春の夜の月 (Yosano Akiko)

Downtown Kyoto

passing under the entrance 
of a rouge shop

that guy there is cute-

beneath the moon of this spring night.

The atmosphere of this poem is very optimistic and filled with a flowery feeling of love, which we can observe from her bold expression: "that guy is cute." Although the moon traditionally elicited melancholic thoughts, here the spring moon illuminates a handsome man passing under the gate of a rouge shop, perhaps buying a present for his wife or girlfriend. In the eyes of the female protagonist of this poem the man looks attractive. The figure of the man illuminated by the moon expands the romantic mood of the poem. But more importantly, the moon is illuminating an object of the female protagonist's sexual desire. This fact qualifies the girl in the poem as a modern woman. It also clarifies Akiko as a modern (female) poet.

In a book about criticism of the new wave tanka at the time, which was published in the same year as Akiko's Tangled Hair, called The New Wave Tanka Review (Shinpa waka hyōron, 1901), a commentator complained that Akiko, "as a female poet, is too vulgar. I do not understand why a poem like this is included in Tangled Hair" (Hiraide 14). His review tells us how Akiko's poetic expression was new and sensational at the time. Many poets and critics criticized her because of her bold expressions of love and desire. Itsumi Kumi, a major scholar of Yosano Akiko, and an editor of Collected Works of Yosano Tekkan and Akiko, mentions this bold expression in her book, and says that this was a very typical expression of Akiko. "A figure of an urban commoner man, which is illustrated in a very natural way, has various dreamy feelings in it, and that makes us feel something similar to traditional Japanese painting. 'That guy there is cute' is bold and 
very representative of Akiko" (Itsumi 193). Akiko's expression of her passion for loveher desire to feel love - is beautifully illustrated with the dreamy atmosphere in the poem, which captures a prosaic modern "urban commoner man" and the scenery of downtown Kyoto and juxtaposes it with the man's good looks seen in the moonlight. The combination of bold expression and decorative, beautiful dream language is, according to Itsumi, what we now expect from Akiko, and I argue that her use of the moon is particularly important. The moon helps to make an Akiko poem easily recognizable as hers.

Not only the boldness of her expression of love but her use of the moon is something that also differentiates this poem from a moon poem found in traditional waka. Here is an example of a classical waka, composed by a female poet, Akazome Emon (956-1041), who lived one thousand years before Akiko.

\section{やすらはで寝なましものをさ夜ふけてかたぶくまでの月を見しかな}

(Akazome Emon, in Mostow 316)

Though I'd have preferred

to have gone off to bed without hesitating, the night deepened and I watched the moon till it set!

(Mostow 316)

The female protagonist is perhaps, Akazome Emon herself. She is passively waiting for somebody under the moonlight. Regarding the romantic relationships in the Heian period, this woman's action of waiting is something traditional in Japanese poetry, according to Sarah Strong: "a large number of women were placed in a position of 
waiting for their men, poems of tedium and longing were standard fare" (Strong 178). As the use of the moon in romantic longing poems in the Heian period shows, this passive action of waiting goes along with the melancholic thought, which is elicited by the moon. In other words, Heian women often waited under the moonlight for lover's visits like in the poem above. In addition, there was a tradition that the moon should be considered to be the autumn moon unless a poem contains a word directly indicating a different season. Heian aristocratic women in waka poems were waiting for their lovers mostly under the autumn moon - a time of year when romance would fade.

\section{The Modern Girl's Pale Moon}

Even though women in traditional waka poems usually take a position of waiting, Akiko's female persona often act on their impulses: sometimes watching a man buying a present for his girl and thinking "that guy there is cute"; sometimes her poetic woman even chases a man she loves. For an example of the latter from Tangled Hair, Akiko's female persona is not passively waiting for her man, instead she follows after him. In real life Akiko pursued Tekkan. The poem captures the excitement of young romance which though sometimes adventurous can be accompanied by immature hesitation. The moon here seems to inspire this young lover to go after what she wants, which would have been shocking to people living in the Meiji Period.

しのび足に君を追ひゆく薄月夜右のたもとの文がらおもき (Yosano Akiko)

Following you on foot stealthily in this pale moon evening 
So weighty, the letters already read in my right sleeve.

One can see the complicated emotions of a young girl in love, such as hesitation and adventurous excitement. Together with poetic techniques such as hypermetric (ji-amari) lines Akiko's diction amplifies this feeling, and this emotion is gently veiled and beautifully ornamented with the pale light of the moon.

Akiko's diction often enriches the mood of the poem. In this poem, shinobi ashi (on foot stealthily) and fumigara (letters already read) are words that signal to the reader complicated and romantic feelings of the young girl in love. Shinobi ashi has a nuance that someone is following somebody sneakily, and the person following does not want the person followed to realize that he or she is following them. As he argues how Akiko's statement of love was bold, Shinma tells the reader that even wife and husband hesitated to walk on the road together in the Meiji Period (Shinma 50). It was common for wives to walk a few steps behind men in traditional Japan. Shinobi ashi here tells us that Akiko's girl persona desperately wants to be near the man she longs for. Fumigara means letters already read. Gara is used for something that has completed its mission, and about to be trashed and forgotten. However, here, Akiko's poetic persona keeps fumigara in her right sleeve. Itsumi writes, "They were very important for the poet when she was young." She adds: "The word 'heavy' indicates that these letters were mentally heavy for the poet" (Itsumi 66). Although readers might think that letters one can carry in one's sleeve cannot be very heavy (omoki), Akiko's female persona feels that the letters are heavy, not because of the physical weight, but for their psychological import. 
The poem's final line gives us the sense that the letters are crucial for her in her pursuit of love.

Besides her unique choice of words, her intense emotional content is the key to interpreting all of Akiko's poems. Her poems are usually so filled with emotion that they often exceed the limitation of beats of the tanka form (31 morae). Even though the first line of tanka usually is composed of 5 morae, the first line of this poem, shinobiashi ni has six morae. The complicated, romance-related hesitation, which is not strong enough to stop her from chasing the guy, is captured in this hypermetric line. According to Jon Holt, excessive (ji-amari) verses can be skillfully used by poets to either make the mood expansive or accentuate a passionate feeling. "These poems with excessive (ji-amari) verses have to break the bounds of thirty-one syllables because their lyric content is bursting at the seams" (Holt 343). He also mentions, "the excess beats can mimetically enhance the images of the poems, often in accentuating quantity expressions, making the mood more expansive, or accentuating a passionate feeling" (Holt 343-344). Akiko's female persona here has a contradictory feeling of passion because on one hand she is hesitating to show her love, but on the other hand, she is tracking after him anyway. She is conflicted. One can see her complex emotions as she vacillates between hesitation and action. Akiko's hypermetric line perfectly captures this deep complex emotion.

As mentioned earlier, Tangled Hair is a well-studied collection of tanka, and scholars widely differ on what to think of maidens that appear in the verses. Even in this poem, Itsumi Kumi contends that this poem captures the lively heart of a young girl. Sarah Strong, an American scholar, argues that Akiko's poems changed the role of 
women in the waka tradition. Readers can easily imagine that sneakily chasing one's love can create a certain type of excitement_-for an immature girl or a mature woman. Along with the romantic excitement of following after a guy she loves, here, we can see an almost adventuresome feeling of hiding oneself while chasing somebody. Itsumi says, "It well captures the lively heart of a young girl. We can imagine a somehow thrilling and interesting scene." (Itsumi 66). The girl is trying to keep her feelings inside of her as she is chasing her love. Perhaps the man realizes that she is following him, but the reader cannot really know what is going to happen. This situation gives some thrill to the verse. This thrill perhaps stimulates young girl's passion and excitement. The girl in this poem is not just passively hiding her body and feelings from the lover, but actively chasing (oiyuku) him. In other words, she is hesitating to show that she loves him, but she physically and actively follows anyway. When one compares this with a female persona's position of waiting in traditional waka poems mentioned by Sarah Strong, we can see that the female persona of this poem is modern.

The moon in Akiko's poems sometimes enhances the poem with the combination of its unusual appearance and the rich emotions in the poem. The reader senses complex emotions of the protagonists and their relation to the image of the moon, here a thin, a hazy or a cherry moon as opposed to a generic moon. The pale moon night (usuzukiyo) illuminates the entire landscape of the poem and expands the romantic feeling. The moonlight emphasizes the exhilaration of the girl protagonist's romantic feelings, as it helps her to hide from the man she is chasing. The pale moonlit night (usuzukiyo) gently illuminates the scene. The clouds or mists in the night sky blur the moonlight, and this 
misty pale moon gently veils Akiko's female persona and her excitement of love. The usuzukiyo allows her to be more sneaky.

The pale moon night is somewhat ambiguous word as a seasonal word since some scholars consider it as a seasonal word of autumn, and others claim that it is a spring word. Because the moon itself is considered as a seasonal word for autumn in the waka tradition, some people argue that usuzukiyo is an autumn word. On the other hand, as mentioned above, usuzukiyo is associated with mists, which is the very thing that makes the moonlight pale. Since the misty moon (oborozukiyo) is used as a spring word from as early as The Tale of Genji (ca. 1000), some scholars categorize usuzukiyo as a seasonal word for spring. For instance, in The Names of the Moon (Tsuki no namae, 2012), a Japanese poet Takahashi Junko introduces usuzukiyo as a name of the spring moon along with other names for the moon associated with mists such as oborozuki, aburazuki, engetsu, and tangetsu (28). Considering the exhilarating mood of Akiko's poem and the pale light helps her to secretly trail her love, it is not a mistake to take this moon as a misty spring moon. The role of the spring moon here, further amplifies the exhilarating feeling of a young girl's romance. This use of the spring moon was something modern at the time in waka and tanka.

\section{The Joy of Love on Moonlit Nights}

Another characteristic of Akiko's spring moon, which differentiates it from the traditional poetic depiction, is the fact that Akiko's romance is, in most cases, something happening in the poem. She described her happiness when in love. Love which tenderly 
embraces her and makes her dream of more love. This is very different from poems about love or romantic affairs in the past. Again, it is very common to write poems about romantic longing and waiting. In other words, traditional poets composed poems about love that was not happening at the moment.

Akiko composed the poem below in 1901. At the time, Akiko was twenty-three years old, in the middle of her romance with her future husband, Yosano Tekkan (18731935).

清水へ祇園をよぎる桜月夜こよひあふ人みなうつくしき (Yosano Akiko) Cutting across the Gion area to Kiyomizu temple, A night of cherry blossoms and the moon beautiful, each and every face I meet this night

Her happiness from her romance with Tekkan puts Akiko in a romantic, dreamy mood and thus makes her see everyone she meets that evening as beautiful. Because she is in the bliss of romance, which is associated with the cherry blossom moon, everyone looks beautiful as she sees things through her lens of happiness. This exhilarating feeling of romance, which makes one dream and makes everything beautiful, is something everyone experiences in their life. A Japanese poet, Nagata Kazuhiro wrote: "I would like to interpret the exhilarating and flowery atmosphere of this poem as a fresh excitement of one's youthful days" (Nagata 42). 
This "fresh excitement of one's youthful days" is something we can often find in Tangled Hair, and the association of this excitement and the spring moon is something unexpected from the perspective of the traditional use of the moon in Japanese poetry. "Excitement" is obviously different from something melancholic; thus, I would argue that Akiko used the spring moon with the association of the excitement of love to create a new perspective in tanka. Nagata argues that "there is no clear evidence to the fact that this was the Kiyomizu and Gion that Akiko walked through together with Tekkan, but the atmosphere of this poem is filled with the rich scent of two lovers walking together" (Nagata 42). As mentioned by Nagata, Akiko consumes the rich scent of romance here; in other words, the female persona in the poem is in love. Thus, this poem is an excellent example of the fact that in Akiko's poetry, love exists at the moment captured in the tanka.

Regarding the association of the moon and the spring, there is one crucial fact that should not be overlooked in this tanka. The word contains the moon, sakurazukiyo (a night of cherry moon), and it is a word created by the poet. Itsumi mentions this fact: "It is said that sakurazukiyo is coined by Akiko" (Itsumi 135). So what does Akiko's original word do in the poem? Akiko herself explained it in her book of tanka theory, How to Compose Tanka (Uta no tsukuriyō, 1915); "The moon is blurred by the scattering cherry blossoms. This is the night that makes people come and go, each and every man and woman is beautiful" (TAZ 15:30). The scattering flowers blur the moon, and perhaps, also blur the people's faces who are coming and going on the street of Kyoto. The combination of the scattering flowers, blurred moonlight, and most importantly, the 
excitement of romance make everything seem beautiful in Akiko's eyes. The spring moon expands her romantic feeling. The moon can make a woman fall in love with the world. This "cherry moon night" (sakurazukiyo), as with "on foot stealthily" (shinobi ashi $n i$ ) in the previous tanka, expands the mood of the poem by creating a six-syllable hypermetric line. The structural expansion of the poetic meter enhances expansion of the poet's emotions.

This flowery excitement can be found in another poem in Tangled Hair. In this poem, the female protagonist comes out to a field of flowers because she feels that somebody is waiting for her.

なにとなく君に待たるる心地して出でし花野の夕月夜かな (Yosano Akiko)

I felt somehow

he is waiting for me

and I went out to the flowering field

this is the night

of the early evening moon

The feeling that "you are waiting for me" is something different from the figure of traditional women in Japanese poems like Sarah Strong analyzed. Akiko’s female persona does not passively wait for somebody but feels that somebody is waiting for, longing for, and wanting her under the moonlight. This is entirely different from women's traditional waiting in Japanese poetry. In the old days, a woman waited for her man with melancholic feelings of longing under the autumn moon, and wished for her lover to come, but Akiko's woman somehow feels that her lover is waiting for her and she goes out into the field. She does not sit and wait, and she does not soak her sleeve 
with tears. This is a modern woman, who moves to a man who waits for her-the opposite situation from a Heian Period woman.

The phrase nani to naku ("somehow") maximizes the dreamy feeling of this poem, the female protagonist is feeling that somebody is waiting for and wanting her, but it is still uncertain. It could be a romantic dream. This "somehow" adds the flowery, dreamy atmosphere to the poem, and makes readers feel that they are dreaming in a calm and optimistic mood of love. Maybe the moon makes her unsure, but in a good way. A Japanese literary critic Shinma Shin'ichi claims that this flowery feeling in the poem can be Akiko's poetic imagination: "It can be poetic imagination, in which she beautifully sings of a dream of a young girl" (Shinma 147). For a young girl to dream of love might not be new in the context of Japanese poetry, but for the moon to assist her in actively pursuing her love outside is a new and unique use of the moon. No sense of melancholy is here. Under the spring moon, she is dreaming her romantic dream, and it makes her feel "somehow" somebody is waiting for her. The season is different from the one traditionally associated with the moon, and the atmosphere is also very distinct from the traditional Japanese melancholic moon feelings.

It is a well-known fact that Akiko later came to hate most of the poems she composed in her early career, but this poem is one of the very few poems she always liked throughout her lifetime (Itsumi 32). This fact tells us that this flowery atmosphere, the excitement of romance, and "a dream of a young girl," which Akiko felt under the spring moon, is very pivotal and something inspirational for her. 


\section{The Beginning of Akiko's Romantic Spring Moon}

We can find a clear example that shows how vital the spring moon was for Akiko from the beginning of her career as a poet. The poem below is her very first published poem, which published in 1889 under the name of Hō Shō before she starts calling herself Akiko. The title of this poem is "Shungetsu," which means, "The Spring Moon." A hazy moon is illuminating love in action.

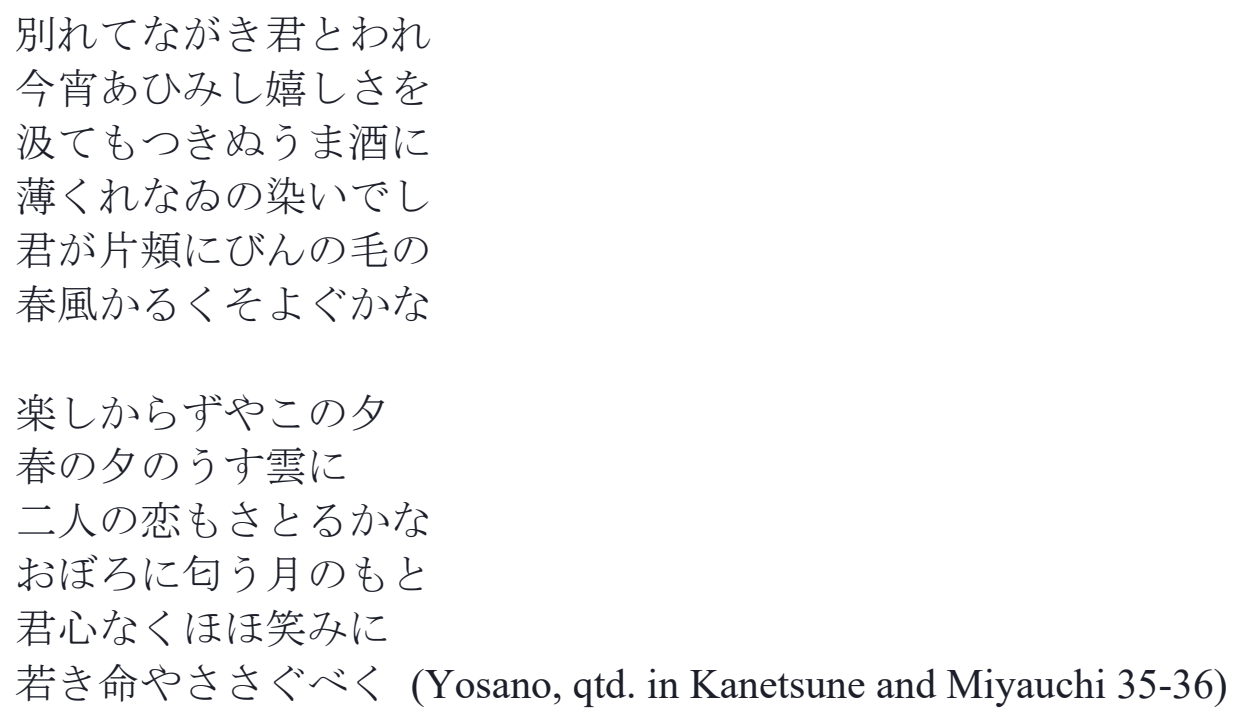

Are we not happy tonight?

Spring in its thin evening clouds

must know our love!

Beneath the hazy moon's glow

shall I offer my young life

to your artless smile? (Beichman 72) 
The first stanza of the "The Spring Moon" is the voice of the boy, and the second is the girl. A scholar of Japanese literature, Janine Beichman, says, "it was a dialogue between two lovers meeting under the spring moon after some time apart" (72). In this poem, one can observe the origin of Akiko's affinity for the spring moon, which is, as mentioned above, associated with the happiness of romance. The happiness of love is scattered throughout the poem. For example, "what joy!” and the sweetness of the wine, which flows forever like her feeling of romance. Also, the color of pink, which often associated with passion in her poems in Tangled Hair, tells us that she feels extremely passionate about her lover.

This poem is often compared with poems by Shimazaki Tōson (1872-1943) who is another major figure of the movement of Japanese romanticism. Scholars argue that Tōson's poem “A Song of Spring” exerted a strong influence on the young Hō Shō (Akiko). Beichman says that Akiko's poem “too derivative (in this case, from Tōson) to be compelling" (72). Her opinion is shared by many scholars and her first poem tends to be overlooked as derivative of Tōson's poem. However, I see her first poem as critical in understanding the origin of her unique use of the romantic spring moon. This led later to a new appreciation of the moon in Japanese poetry.

The most famous collection of poems written by Tōson is Collection of Young Herbs (Wakanash $\bar{u}, 1897){ }^{3}$ One can find examples of both spring moon and a young girl's romantic feeling in spring; however, there is not a combination of these two. In

\footnotetext{
${ }^{3}$ In Nihon Kindai Bungaku Taikei (here after NKBT) 15.
} 
other words, Akiko's romantic spring moon is not something influenced by Collection of Young Herbs. Here is an example of a romantic feeling in spring, which is called "A Song of Spring" ("Haru no uta") by Tōson.

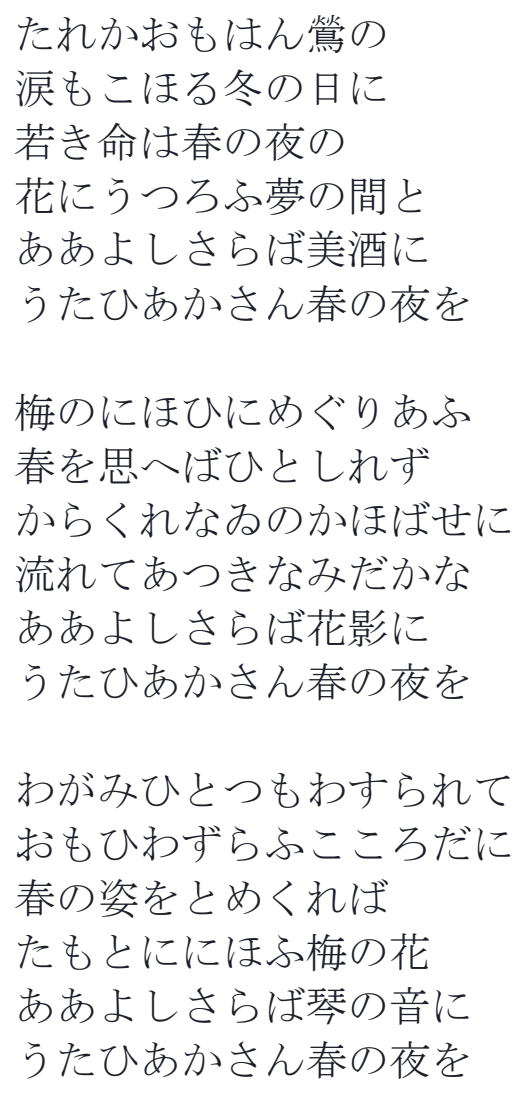

(NKBT 15: 83-84)

A winter day, even bush warbler's tears freeze Who thinks about a young life, dazed by the petals of a spring night in between the dreams Oh well, then, in praise of the delicious sake I will sing through the spring night

Fate brings me to the scent of the plum As no one knows, I think of spring On my red cheeks warm tears falling down

Oh well, then, in praise of the shadow of blossoms 
I will sing through the spring night

I even forget about my body

Because of concern in my heart

When I came and sought the shape of spring

There is the scent of plums on my sleeve

Oh well, then, in praise of the sound of the koto

I will sing through the spring night

There are many similarities between "The Spring Moon" and "A Song of Spring." In

Tōson's poem, the night of spring is associated with young life, the dream of being dazed by flowers, and even delicious sake can be found in the first stanza. Each of these three stanzas end with "Sing all night, in this spring night," from which we can observe exhilarated passion from the romantic feeling. In his commentary of Tōson's Poetry (Tōson Shishū 1971), a scholar of Japanese early modern literature, Seki Ryōichi, mentioned that several lines after "young life" express the carpe diem philosophy of living for the moment and only pleasure-seeking. This idea is quite similar to the theme of "The Spring Moon," in which Akiko sang of the momentary joy of seeing her love. As often mentioned, the moods and feelings of these two poems are comparable. Momentary youthful joy and self-indulgence describe the mood of these two spring night poems.

Nonetheless, in Akiko's poem “The Spring Moon," the moon enhances the intensity of the girl's romantic feeling. "Hazy moon's glow" appears towards the end of the poem, which is the climax of the girl's emotion. "Shall I offer my young life?" explains how much this young girl is willing to devote herself to her lover. She is almost ecstatic with love. The very last line articulates the object of her romantic feeling, which 
is the adolescent's "artless smile." Most importantly, the hazy moon is casting light on this smile, and on the girl's romantic joy. On the other hand, there is no moon in Tōson's "A Song of Spring." This fact reveals that Akiko's romantic feeling under the spring moon is something not derived from Tōson's influence, but is her original creation.

At the very beginning of The Collection of Young Herbs, there are six poems about young girls, for which Tōson's designated the name, "Six Maidens." Each poem is given the name of a girl and is associated with complicated feelings of young girls. These poems illustrate the romantic, dreamy world that exists in young girls' hearts. This is very similar to the feelings Akiko described in her tanka; however, Akiko chose the moon as one of the poetic themes to expand the feeling of love while Tōson did not.

In the first poem of "Six Maidens": "O-yo," one can find the spring moon in the third stanza. It is not associated with young love but describes the young girl's confusion and dream of the ancient era, the Heian period.

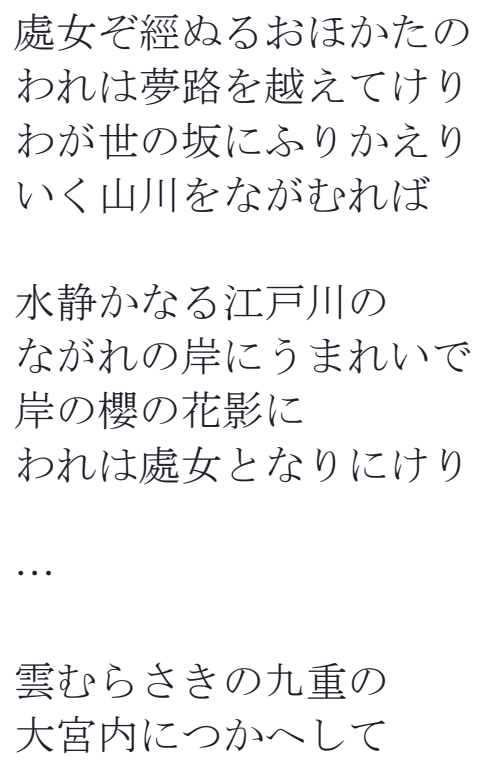


清涼殿の春の夜の

月の光に照らされつ

(NKBT 15: 52)

Like most maidens go through, I came across the traces of dreams

A point in my life, I look back at the hill

I watch the mountains and rivers I passed

Quiet flowing Edo river,

I was born at the bank

In the shadow of the cherry blossoms

I became a girl

$\cdots$

I serve the nine-layered palace

Under the purple clouds

The spring night of the palace of Seiryō

While the moon shines on me

The first two stanzas of "O-yo" give the context to the reader. From the very first stanza, one can find that she is looking back on the paths she traveled, which is her past life. This is not only the past of her actual life, but it is described as "the traces of dreams" (yumeji). The line "I came across the traces of dreams" tells the reader that this maiden has been dreaming — probably romantic ones. The second stanza reveals the maiden's birthplace and where she grew up and became a girl. What these first two stanzas convey to the reader is something similar to Akiko's flowery dreaminess.

However, the role Tōson gave to the moon in this spring poem is different from Akiko's romantic moon. For Tōson, it is instead a symbol of nostalgia, which is one of the very traditional uses of the moon. The third cited stanza is the one that includes the spring moon. What this stanza describes is nostalgia for the ancient period. One can 
find images of the Heian court culture from this stanza. "Ōmiyauchi" is a word that describes the imperial court, and "Seiryōden" is the palace in the imperial court, which is the private space of the emperor. The nine-layered purple clouds are also related to nostalgia here. Although the Morning Star (Myōjō) poets use purple as the color of romantic passion, this color has been a symbol of nobility in Japan ever since the ancient era. "Nine layers" is also a word that describes the imperial court, which derives from the fact that the king's castle had nine-layered gates in ancient China (NKBT 15: 52-53). As we can see from these facts, except for "the light of the spring moon," the vocabulary in this stanza is all related to the Heian imperial court. The role of the spring moon is to shine on and illuminate these objects of nostalgia, and hence, it is not illuminating or enhancing romantic love.

One can observe the traditional spring moon poem, in which the moonlight makes the object of nostalgia shine and stand out in the poem. The following work from the Kokinshū, by Ariwara no Narihira, best illustrates the nostalgic pathos inspired by the moon.

月やあらぬ春や昔の春ならぬ我が身一つはもとの身にして

(Ariwara no Narihira, Kokinshū, no 126)

Is not the moon the same?

The spring

The spring of old?

Only this body of mine

Is the same body...

(McCullough 52) 
The moon changed and the spring changed, yet the male persona has remained the same. This poem illustrates the pathos of time passing felt by one human being. He is feeling sadness from this feeling as he remembers the moons and springs in the past. Narihira's poem is an excellent example of the association of the moon with the feeling of nostalgia in Japanese poetry. These next two poems resulted in the creation of many nostalgic poems related to the moon and spring.

梅の花たが袖ふれしにほひぞと春や昔の月に問はばや

(Minamoto no Michitomo, Shin kokinshū, no 46)

O! plum blossoms,

Whose sleeves have touched you?

You smell so fragrantly

I shall ask the moon in bygone days

Still shining in the spring sky.

(Yusa, 18)

梅が香に昔を問へば春の月答へぬ影ぞ袖にうつれる

(Fujiwara no Ietaka, Shin kokinshū, no 45)

When I ask of the past

in the scent of the plum, the spring moon

keeps still

glistening on my sleeve

(Cook in Shirane, Traditional Japanese Literature: An Anthology, Beginning to 1600, 614)

These two poems are from Shin Kokinshū (ca. 1205). As with Kokinshū, Shin

Kokinsh $\bar{u}$ had significant influences on the later generations of Medieval poets. Both of these poems contain the spring moon and plum blossoms. In the first poem, like 
Narihira's poem from Kokinsh $\bar{u}$, the moon is something that has not changed from the ancient era. The scent of plum trees evokes the poet's nostalgia, and the poet seeks the answer from the moon. The role of the moon in the second example from Shin Kokinsh $\bar{u}$ is similar to the first one. The plum scent triggers a nostalgic sensation, and the poet asks the moon about the past, but the moon does not answer him. It just triggers nostalgia for him.

As these examples testify, the spring moon and the sense of nostalgia had been conventionalized at least by the era of Shin Kokinsh $\bar{u}$ or the late $12^{\text {th }}$ to $13^{\text {th }}$ centuries. Considering this association of nostalgia and the moon, the moon in Tōson's Collection of Young Herbs is something quite traditional while Akiko's romantic use of the spring moon in something new and modern. Akiko was somewhat familiar with Western literature since the time she was young. There is a record that shows Akiko discussed "European writers like Goethe and Shiller" (Beichman 76) with her literary friends. Akiko herself mentioned western authors such as Tolstoy and Goethe in her writings. Elsewhere, more fully discusses the impact of late Victorian literature on $M y \overline{o j} \bar{o}$ aesthetics (Morton 15). Perhaps the use of romantic moon in poetry was something inspired by the West, but for Akiko, she must have sensed new poetic possibility with it. From the very first poem she published in her whole life, Akiko already had this association with romantic feelings and the spring moon. One might expect that if she felt she could create new associations for the spring moon in poetry, she probably felt free to change the associations of other seasonal moon poetry as well. In the next chapter we 
will see that is what she did. Akiko, as a modern poet, felt that the moon could serve her literary purposes, not that she should be bound by the practices of traditional literature. 


\title{
Chapter II
}

\section{The Summer Moon:}

\section{Yosano Akiko's True Feeling and Her Romantic Sin}

\begin{abstract}
As introduced in the previous chapter, Yosano Akiko modified the traditional ideas and aesthetics associated with the seasons and the moon in Tangled Hair, but why did Akiko do this? Yosano Akiko modified the traditional topics to create new symbols of her "new emotions" (atarashī kanjō) (TAZ 15:47), which were the personal and private emotions each individual human being possesses. The four seasons and traditional topics related to seasons had long been used to reflect the poet's emotions, but they had become over-conventionalized symbols. However, Akiko set her moonlit nights in spring and summer; two seasons perfect to symbolize her romantic feelings as a young woman. She externalized her inner landscapes with her own seasonal views. For example, her moonlit landscapes could embody her jikkan, or true feelings. In this way, she gave new meanings to symbols that had been conventionalized in the Japanese literary tradition for over a thousand years. In other words, at the start of the twentieth century Akiko was creating new uses of traditional seasonal symbols to capture her inner landscapes as a part of the process of revealing the poet's true feelings (jikkan).
\end{abstract}




\section{Creation of New Symbols}

Akiko talks about symbolism (shōchōteki) in her Talks on Tanka. She used this word loosely as a general conceptual term to designate her technique of symbolizing emotion through external objects. She believed that the symbol allows more room for the operation of individual emotion or imagination for poets. Akiko said that one important kind of symbolic expression suggests a comprehensive imaginary reality, which presents an inner landscape that is externalized by way of symbolic images. Makoto Ueda, a professor emeritus of Japanese literature at Stanford University, writes of her method that

it does not express a specific feeling: rather, it suggests a comprehensive imaginary reality that envelopes both the poet's self and the world that surrounds it. Its central image would symbolize not just a happy or a sad feeling but the entire complex of thoughts and emotions unified through the poet's perspective. It would be a pointer directing the reader toward the poet's personal universe, whether religious, metaphysical, or mystical. (Ueda 89)

Her moon and seasons are symbolic expression since they represent joy of love and romantic feeling, which are not just specific emotions but suggest an entire atmosphere or mood for the poem. According to Ueda, this kind of symbolic expression is "the key that opens the door to the poet's private, esoteric world" (Ueda 90). Akiko used term jikkan to designate her private and personal emotion, which she expressed in poetry by using symbols. She fashioned her world filled with the joy and passion of love by using symbolic elements, which include the moon in spring or summer. By doing so, she was trying to express her internal landscape, which includes "the poet's self and the world 
that surrounds it" (Ueda 89). What remarkable here is that Akiko was trying to create new meanings for symbols by re-purposing traditional waka symbols.

To give traditional objects new symbolic meanings, one first has to depart from the tradition. Akiko talks about how boring the usage of traditional topics can be if a poet uses it as a symbol of conventionalized ideas associated with particular objects. In How to Compose Tanka, Akiko clearly mentioned that when poets compose tanka with an established combination of objects and their emotions, the poet ends up becoming "a machine that keeps imitating archaic ideas" (TAZ 15: 81). One immediate example she picked the tedious practice of using the seasons for their traditional use.

In the established tanka practice, the main problem is this: we have set for us the established themes of tanka, so, when spring comes, we read the poem as a spring poem and therefore, we compose on things like new herbs, lingering snow, hail, plum blossoms, etc., so then we also have established for us set limits within which we express our feelings (kanjo) with those seasonal words. Today there is a trend in poetry for people to avoid expressing their individual feelings so that they are totally divorced from the emotions of poets of antiquity. That's why when what should be "to each person their own" (jünin toiro) [ "ten people, ten colors"] you still sadly end up with ten people still producing only one color. (TAZ 15:8586)

Seasons have been conventionalized in the tradition of waka, and certain seasons and seasonal words were often associated with specific emotions and feelings. Haruo Shirane mentions that "The seasonalization of nature in waka was largely a cultural construction" and says:

waka was, first and foremost, a poetry of affect in which certain images evokes specific emotions. This encoding was reinforced and institutionalized by the 
practice of fixed-topic composition (dai'ei), which came to the fore in the mid-to late Heian period and imposed strict rules on the range of associations. For the aristocracy, Buddhist priests, and educated samurai, this secondary nature became a shared cultural vocabulary - a rich repository of emotionally charged images and metaphors - that was used for and, indeed, became indispensable for a wide range of social, political, and religious functions. (Shirane)

What Akiko is arguing here is that poets of the modern era should depart from the emotions conventionally associated with certain topics and start expressing "complicated emotions of modern human beings" (TAZ 15:64).

Being a poet in the modern era does not necessarily mean that one is capable of expressing complicated modern emotions. Even among new wave tanka poets (shinpa), this imitation of traditional poetic symbolism continued. She chose one example composed by a new wave poet (without mentioning who it was):

尼君が経誦し給ふ山寺に月影さして萩の露散る (qtd. in TAZ 15:88)

A nun, chanting a sutra in a remote mountain temple and the moon shines on bush clover dew dripping

Akiko observes the aesthetics as merely consisting of "archaic ideas," which the poet probably absorbed from an old novel or something. Akiko gave a severe rebuke to this poet:

Who among the modern young people will look in a temple yard and be moved by the voice of a nun reading a sutra, or feel tasteful joy with moonlit dews dripping from bush clovers in a nunnery? Those are the emotions that moved 
people's hearts in Heian (794-1185) novels or Kusazōshi in the Tokugawa [16031868] period. (TAZ 15:88)

The moon has been commonly depicted in the waka tradition, and it has often been associated with certain feelings, emotions, and themes as well. This comment by Akiko clearly indicates that she felt that poets of the new era should observe these objects with modern poets' sensibilities and provide modern ideas to match them. In Akiko's estimation, this poem is nothing but an old-fashioned poem even though a poet of the modern era composed it.

Akiko calls departure from traditions "destruction" (TAZ 15:87), which is crucial in understanding Akiko's new creation of symbols. Akiko uses the term "destruction" in the section named "Destruction and Construction" (TAZ 15:87). Ueda explains the "construction" part of her argument. Good poems should contain jikkan, which includes five elements: truth, uniqueness, freshness, excellence, and beauty (Ueda 77). However, Ueda showed little interest in the crucial first step of this "construction," which is "destruction" of the tradition. Akiko explains how important the process of "destruction" is in poem composition:

If a poet observes things with the standard of ideas that already exist, that emotion will be out-of-date, lack liveliness, and will only express old-fashioned emotions (inshü-teki kanjō), as unoriginal as signature seals (han o oshita yōna). However, if a poet can destroy these archaic ideas and try to observe things with new sensations, one will find new emotions, new passions, which excite one's entire body. If one expresses that with language, one can establish a new literature as a result. Plums and bush warblers are cliché. As soon as a poet deconstructs the old, traditional emotional associations and directly observes real plums and bush warblers with a new sensitivity, then we will surely realize that those clichés do not stimulate the sensations of us, people in the modern world. (TAZ 15:87) 
To construct a new idea, one cannot neglect this process of destruction. If the poet does not recognize the traditional associations that have been repeatedly used by waka poets, he/she will likely continue to write conventional poetry. Only a recognition of the past practice and a desire to break from it can lead to innovation. Without the will to "destroy" archaic traditional associations of topics and ideologies, one cannot express jikkan that has "uniqueness" and "freshness." This idea is not applicable just for seasons, the moon, and romantic feelings, but for all new emotions that Akiko wanted to express. In this sense, Ueda probably missed the significant first step prior to her "construction." In contrast to Ueda, Leith Morton did realize the significance of this destruction. “Akiko's purpose," Morton writes, was “to create a diction that was fresh and new, in other words, modern: as far removed from the language of traditional poetic rhetoric as possible" (Morton 25).

\section{The Landscapes of Summer}

Spring and summer are the dominant seasons in Tangled Hair. Akiko chose these two seasons as symbolic of her romantic feelings. Flowery feelings of spring and the passion of summer were significant elements of her inner landscapes, which were the representation of her romantic jikkan.

A researcher of the Japanese language, Miyauchi Tamako, analyzed seasonal feelings in the collections of Akiko's tanka. According to Miyauchi, almost half of the poems in Tangled Hair contain seasonal references. Out of these poems, $51 \%$ of the 
poems are about spring, $34 \%$ of the poems represent summer, $11 \%$ are autumn, and only $4 \%$ of the poems have a sense of winter (Kanetsune and Miyauchi 239). Akiko talks about her early works in How to Compose Tanka. Akiko looked back at the period of Tangled Hair, writing, "I considered romance as the core of my life, so the poems I composed back then were mostly occupied with the jikkan related to romance" (TAZ 15:29). She also mentions that "there were so many childish poems that make me blush with shame." "However," she continues, "I was expressing with my most sincere effort the desire in my life, which was coming from my childish soul" (TAZ 15:34). These facts tell us that the scenery of these two seasons were the landscapes she had in her mind when she was living her life of love with Tekkan. Although she lived through all four seasons while in love with him, spring and summer were the best seasons to symbolize her feelings of romance at that time.

The season of passion, beauty, and confidence in one's self and one's beautythis might well describe how Yosano Akiko illustrated summer through the lens of her jikkan. She symbolized these themes and feelings in her summer poems. In Talks on Tanka, Akiko commented on her thoughts about summer. She considered summer to be a very lively season, full of energy of life. Summertime makes people realize their own beauty. Below is the description of summer in Akiko's eyes.

When the season of summer comes, which is a season full of passion for life, all things (banbutsu) open their eyes of wisdom (eichi no me). Then, they realize their own dignity and beauty. For example, this is the season in which women gain their confidence as they look in the mirror and come to think that they are more beautiful than other women. (TAZ 20:116) 
We can see a strong sense of self from Akiko's expression, "dignity and beauty." The subject of the realization of "dignity" and "beauty" is the seasonally-attuned self. The confidence one has in oneself comes from one's own beauty and this invigorates one's passion to love, presumably oneself as well as others. To Akiko, not only humans but all things (banbutsu) in this world, including things in nature such as trees and flowers, also feel the excitement of love in summer. Summer is romanticized thoroughly through one's heart and one's eyes. Even plants and insects, to which we do not normally attribute such emotions, must feel the power of summer love. In other words, the poet romanticized all characters and objects in her summer poems and they became symbols of the passion of her love.

This romanticized summer, and the ideas which were symbolized and associated with summer, were something different from summer in the traditional waka poems. Haruo Shirane mentions the typical seasonal words of summer in Kokinsh $\bar{u}$, which are cuckoo (hototogisu), the mandarin orange (tachibana), and summer rain (samidare). According to Shirane, the song of cuckoo was "thought to increase one's longing for a lover." He continues, "from as early as Man'yōsh $\bar{u}$ the hototogisu was also associated with nostalgia and longing for the past" (Shirane). The scent mandarin orange became associated with "personal memory" and "nostalgia" like the cuckoo, according to Shirane. Summer in Japan includes a long and intense rainy season (tsuyu). Thus, summer rain became a major topic of that season in the Kokinsh $\bar{u}$, and "they became associated with melancholy thoughts" (Shirane). After introducing these three major topics of the summer poems in Kokinsh $\bar{u}$, Shirane summarizes how the Heian poets formed their images and associations of the summer season. "In short, the summer book 
of the Kokinsh $\bar{u}$ combines the image of the hototogisu with those of tachibana and samidare to create an emotionally textured landscape associated with love, memory, and depression." (Shirane). When one makes a comparison between the Kokinshu tradition and Akiko's use of her romantic summers, one finds that the two are distinctly different from each other.

Instead of depression, Akiko proclaims her joy and love in Japan's hottest, and often most miserable, months. As we saw in the previous chapter, in Akiko's tanka, the object of this joy of love is often in close proximity, as opposed to romantic "longing" for somebody who is not there, which was associated with the songs of the cuckoo. The long summer rain, songs of a cuckoo, or the scent of mandarin orange is not depressing enough to discourage the poet who believes that "songs of love are everywhere in the universe" in the summertime. Shirane notes that Japan actually has two seasons of summer, given its location on the monsoon-impacted Asian continent, and that both are extremely trying in real life for Japanese people. Akiko however, apparently did not complain about the oppressive heat of two-or even one-summer season. At least regarding the summer moon poems in Tangled Hair, a sense of depression was not a component of her poems. The feelings Akiko symbolized with summer and objects of summer were entirely different from the ideas symbolized and conventionalized in waka tradition—or in the reality of Japan's weather. 


\section{The Summer Moon Poems in Tangled Hair}

In her summer moon poems, as she did in spring moon poems, Akiko captured the romantic mood felt by her young girl's persona. This young girl's flowery exhilarating mood can be observed in some of Akiko's summer moon poems. In this sense, the poem below is somewhat close to her spring moon poems. Note how there is no classical sense of melancholy — nor, one might note, any realistic feeling of muggy summer lethargy. This summer moonlight poem, like the springtime moon poems, clearly expresses Akiko's jikkan inner landscape.

月の夜の蓮のおばしま君うつくしうら葉の御歌わすれはせずよ (Yosano Akiko)

Moonlit night above

the lotuses, the bridge railings

You, so beautiful-

I've not forgotten your

poem on the leaf reverse

(Modified from Beichman 100)

This poem is filled with the sweet feeling of romance. "I've not forgotten" is a strong declaration of the depth of the poet's love. "You, so beautiful" is a direct expression of the joy of love. She does not even hesitate to state the beauty of "you." According to Itsumi, "you, so beautiful" (kimi utsukushi) encapsulates the exhilarating feeling of the beginning of young love. Akiko was intoxicated with her romantic feeling caused by her encounter with Tekkan, and she expressed that feeling with the line 'You, so beautiful' (Itsumi 254). Also, most importantly, the poem starts with "moonlit night," which helps 
her to perceive the beauty of "you." In this sense, this poem has something in common with the sakurazukiyo (cherry moon) poem, which was introduced in the previous chapter. In both poems, the mood of the moonlit night makes the girl see the beauty of things and people. The moon works like a filter that enhances the beauty caught in her eyes. Also, Akiko chose to show this image of the moonlit night at the very beginning of the poem, which intensifies the importance of the moonlit night in the poet's mind and enhances its romantic mood. This landscape of the moonlit night is yet another strong example of her jikkan. Akiko used the moon to express her romantic feeling not realistically but symbolically.

Composed right after Akiko met Tekkan in the summer of 1900, the "you" of the poem is most likely her future husband, Tekkan (Itsumi 254). Indeed, Akiko wrote many poems about his beauty. In Akiko's summer moon poems, it is not uncommon to find a handsome figure of a male Buddhist monk, which sometime is associated by some scholars with Tekkan. ${ }^{4}$ Tekkan's father was a devoted Buddhist, and Tekkan himself was more than familiar with the teaching of Buddhism. There is a record in Itsumi's other book, A Critical Biography of Yosano Hiroshi and Akiko (Hyōden Yosano Hiroshi Akiko), where Itsumi learned that Tekkan actually entered the Buddhist priesthood (tokudo) at Nishi Honganji in Kyoto around 1889 at his father's insistence. Although readers cannot definitively know if she was thinking of Tekkan when she composed these summer moon poems that feature a Buddhist monk, one can at least find a connection between her real life and her poetic persona's romantic feeling toward Buddhist monks.

${ }^{4}$ Beichman 105; Itsumi 35. 
The figure of the Buddhist monk is usually the object of her romantic jikkan in these poems. Monks were pivotal figures to complete her romantic landscape, her symbolic universe of love where even the ascetic cannot be removed from love and romance, especially when seen under the light of the moon.

In her summer moon poems, lotus flowers are another common element one encounters. This summertime flower, which has been a seasonal word of summer in the waka tradition, marks these verses as summer poems. Another function of the lotus flower is to symbolize Buddhism. This flower has been traditionally used as a flower that embodies the Buddha and his teaching. Shirane writes

Buddhist iconography also made use of seasonal, trans-seasonal, and talismanic natural images. The most important of these was the lotus flower, iconographically the seat for the meditating Buddha, which symbolizes enlightenment or purity amid the mud of the surrounding pond or swamp. (Shirane)

Even though the lotus flower is a word, which gives the feeling of summer to a poemcertainly a crucial component of Japanese waka - it also works as a Buddhist iconograph. Furthermore, in Akiko's poems, the lotus works to deepen the moonlit inner landscape of her maiden protagonists.

In addition to monks and lotus flowers, the moon is traditionally associated with Buddhism in Japanese culture, and we can find examples of Akiko using all three symbols in many of her summer moon poems. Interestingly, Tekkan made explanatory notes on Izumi Shikibu's use of these symbols in her poetry, which Tekkan and Akiko collected their analysis, published as a book in 1915. In this Annotation of an anthology 
of Izumi Shikibu, Tekkan commented on the moon as a symbol of Buddhist enlightenment.

冥きより冥き路にぞ入りぬべきはるかに照らせ山の端の月

(Izumi Shikibu, in $T A Z$ 13:453)

From darkness

Into the path of darkness

Must I enter:

Shine upon me from a far,

O moon above the mountain crest.

(Cranston 6)

Izumi Shikibu has polluting thoughts (bonnō) such as romantic ambition and delusion, but she goes to an even darker path because of her suffering. That is why she then seeks guiding light from the moon, which also refers to a manifestation of the Buddha. Tekkan comments on the poem: "The 'moon above the mountain crest' is a metaphor of the light from the Buddha and the teaching of Shōkū [a Buddhist monk, 910-1007]" (TAZ 13:453). He then comments on the court ladies in the Heian period (794-1185) and how educated they were. "Thinking of the fact that they are referring to Chinese texts and Buddhist teachings without any trouble, we know these perceptive ladies at the time had philosophical, academic, and religious knowledge, which was in no way shallow at all" (TAZ 13:454). This commentary tells us that they were very aware of Buddhist iconographies and their functions.

However, his own wife, Akiko, was using traditional symbols of Buddhism in a more humanistic and modern way in Tangled Hair, even though she also has an in-depth knowledge of pre-modern Japanese literature and Buddhist symbols. For Akiko, the 
greatest significance of a moonlit night is its potential for imparting a romantic mood. Akiko's use of the moon is significantly different from Izumi Shikibu in the poem above. When we compare Izumi Shikibu's poem and the previous example by Akiko, we see that Akiko associated the moon with complicated individual feelings rather than using it as a Buddhist iconograph, which was shared, common knowledge.

Through her poetic lens of true feeling, Akiko transforms even these spiritual iconographic elements into participants of romantic summer. In summer, which is "a season full of passion of life," even these spiritual symbols can kindle the fire of love. These symbols of Buddhism also should "talk in a language made of the scent of passion," like all other things. The sentences below explain to us that she finds the feeling of love from "everything" (banbutsu), not just from humans. In other words, everything - regardless of whether it is a maiden intoxicated with her romantic encounter with a handsome man or an ethical iconograph can play a part in Akiko's summers of love.

When summer comes, everything kindles a fire of love. Even lilies and hawthorns in fields talk in their language made of the scent of passion. Songs of love are everywhere in the universe. (TAZ 20:117)

Although the cynic might view Akiko's Talk on Tanka as mere hyperbole and hollow rhetoric, as we can see, Akiko strongly felt that in summer the feeling of love resonates in everything, every living and non-living thing. The poet needed to remind her modern audience of this aspect of poetry. Even in the modern eras of the Meiji and Taisho (18681926), Japanese needed to be reminded by Akiko that humans can be energized with the 
power of love along with other objects in nature. That is why Akiko's choice of her society's most ethical, most moralizing humans - those preachers of the Way, the Buddhist monks - are no exception to the pull of Akiko's romantic moonlit summer nights. In fact, all the other Buddhist icons, lotus flowers and the moon play an equally guilty role in turning up the summer heat. In Tangled Hair, romanticized Buddhist monks, lotus flowers, the summer moon serve Akiko's jikkan aesthetics.

In Akiko's verses, traces of premodern religious sensibility in her thought, can be made to serve her modern sense of jikkan. Even the Buddhist texts, the sutras, when intoned for salvation, cannot help but serve to amplify the romantic mood in her summer poems. In the following tanka, we have yet another—here a fourth—religious symbol appropriated for its romantic potential. The entire tanka creates a romantic and somewhat mysterious atmosphere.

\section{経にわかき僧のみこえの片明かり月の蓮船兄こぎかえる (Yosano Akiko)}

Rowed by my brother, returning

In the lotus-viewing boat-

O this priest, Face half-seen in moonlight, Voice too young for sutras!

(Modified from Goldstein and Shinoda 71)

The moon here works as a light that brings into focus the beauty of the male ascetic. Half of the monk's face in profile is lightened by the moon, which makes his face more beautiful in the poet's mind. His voice reverberates from afar though his face is only "half-seen in moonlight." Twice hidden, twice removed from her, his mysterious 
presence makes the mood of poem all the more romantic. The mystery is not in his spiritual journey but in when will the natural elements yield him up to the young girl. Another male character in the poem, "brother" (ani), is even more mysterious. There are multiple ways to think about the role "brother" plays on the boat. Itsumi's interpretation is that the priest and the brother are on the same boat, talking to each other. Then, her female persona hears the voice of the priest and thinks that his voice is too youthful to be dedicating himself to sutra reading. Itsumi wrote that this brother can be another poet Akiko admires, but Itsumi also introduces Sato Haruo's idea that this is Akiko's actual brother (Itsumi 251). On the other hand, Konno's writes that, this "brother" and the priest are the same person, but Akiko just has different ways to call him. Konno interpreted this "brother" as just a way to call an older male person with familiarity (Konno). Both scholars stress the similar but different aspects of the familiarity of this "brother." Either way, the existence of the brother talking to the priest or her calling this priest her "brother" brings him emotionally closer to the speaker. The addition of "brother" adds to the mystery of this already mysterious poem, but it clearly deepens the romantic mood here.

The poem's entire Buddhist (but really non-Buddhist) landscape itself is the externalization of her inner landscape, which is a creation of her jikkan. We wonder what is real and what is unreal. Akiko's converts the landscape symbols in a new configuration of reality that is very much representative of modern Japanese literature and its emphasis on the individual. Jikkan is thus as way for the poet to reveal her personal tastes, to reveal her individuality. 
Thus far, these examples of her tanka have shown contains very traditional images: the spring moon and the summer moon. As Akiko explained by herself, these topics can be boring if one uses them with the sensibilities repeatedly expressed in traditional waka. However, as she said, if one invests these images with fresh meanings, one can create "new literature" (atarashii bungaku) as a result. From the examples showed, we can find that Akiko uses both the spring moon and the summer moon in a similar context to describe similar feelings. In other words, Akiko was using these images as symbols of her individual, romantic feelings. Thus, when we observe her use of the moon and seasons, destruction and "innovation" might be an appropriate term to describe this willful act of her deformation of canonical waka poetry.

\section{Buson's Moon and Akiko's Moon}

Akiko was strongly influenced by the haikai poet, Yosa Buson (1716-1784). When we compare these two poets' use of the moon, it shows clear difference between these two poets. Akiko's use of the moon helps to shape her romantic atmosphere, which is an inner landscape in the poet's mind, or her jikkan. Buson's moon was also something new at the time he wrote, compared to the traditional waka use of the moon before his time, before the Edo period (1603-1868). Prefigured by Matsuo Bashō (16441694), haikai poets in the early Edo period were creating a new combination of words and ideas. 
Haikai spirit (haii) originally referred, as the word haikai itself did, to the comic or humorous element (kokkei) in popular linked verse, but it also came to imply, as it did in the renga-style period, in the mid-1680s, the discovery of new worlds or perspectives, especially those that went against convention and tradition and that manifested themselves in the constant search for new associations or new approaches to the seasonal topic. (Shirane, Traces of Dreams 211)

In Traces of Dreams, Shirane explains how poets were also applying new meanings to the traditional topics in their haikai aesthetics. The significant difference between these haikai poets' "search for new associations" and Akiko's new use of symbols is that haikai poets "went against convention." Haikai poets often used, or implied, classical waka themes to juxtapose them with their "new associations," and such juxtapositions lend to their poems a humorous mood. Because readers at the time knew "convention and tradition," they sensed the incongruity and this often led to a humorous tone. In other words, haikai poets were consciously subverting old conventions to create new works.

Buson's poems contain the moon with a sexy feeling. In the first poem below, the word "hazy moon" (oborozuki) tells us that this is a spring moon poem and another example has the words "the summer moon" in it. In these poems, the moon is not a symbol of a romantic atmosphere, but the symbols of a suggestive and sexy feeling, which are juxtaposed with classical elegance. This incongruity makes these hokku (the first haikai sequence verse) quite funny. Importantly, Buson used traditional ideas associated with the moon: the elegance of the hazy moon and the refreshing coolness of the moonlit summer night combine to bring out the bawdiness in these poems.

さしぬきを足でぬぐ夜や朧月 (Yosa Buson) 
The night I am taking off

trousers with my legs -

the hazy moon

河童の恋する宿や夏の月 (Yosa Buson)

The inn where

Kawataro falls in love-

the summer moon

The more aware we are of the associations of the diction, the more we understand how funny and ribald Buson is. Shirane wrote, "Haikai humor typically resulted from raising the expectation of $\mathrm{X}$ and then giving $\mathrm{Y}$, by emphasizing a difference that ran counter to established conventions and expectations" (Shirane 12). For example, "Sashinuki" is a man's trousers worn in the Medieval Period. In the commentary section of The Collection of Buson's Haiku, Tamaki Tsukasa, a scholar of Japanese literature, describes this poem as a scene of a secret night affair and the hazy moon (oborozuki) elicits the amorous mood. He defines that the action of taking sashinuki off with one's foot as a slovenly (jidaraku na) act, which a nobleman never does when he wears a proper hat (suikan eboshi) during the daytime (Yosa). In other words, this man, who acts like a nobleman during the daytime, becomes a nighttime lecher by completely neglecting daytime behavior. This combination of elegance of the hazy moon and the garment evokes the mood of the imperial court, but the man's naughty, slovenly lust during a onenight affair is very much rooted in the then-modern world of haikai. Nevertheless, these verses are quite different from those by Akiko with her romantic moons. Although both 
poets used erotic expression, Akiko projected her romantic dreaminess, while Buson made his poems humorous.

The second poem on Kawataro also has sort of an unexpected combination. The refreshing air of a summer night juxtaposed with a lecherous monster (yōkai). Kawataro (also known as kappa) is a monster that exists in Japanese folklore. Tamaki quotes a dictionary in Edo period called The Names of Things (Butsurui Shoko, 1775), which describes a Kawataro as: “(a monster) that likes sexual (sumo) wrestling, captures and drops humans into water or rapes women with its magical power" (Tamaki in Yosa, The Collection of Buson's Haiku [hereafter Tamaki]). The moon in Buson's poem shines a spotlight on this perverted monster. One cannot imagine it existing in Akiko's poetry of dreamy Meiji young ladies. The elegant moon in these two verses is scandalized by illuminating bawdy funny images from the world of commoners. Akiko would rather have the moon serve a different purpose: to plunge us into her personal romantic world.

Unlike Akiko, Buson sometimes wrote love poems from the viewpoint of a male perceiving something visibly sexy, which gives men a visual arousal. The poem by Buson below clarifies this difference between the two poets. Also, more importantly, the use of the moon as a metaphor for a beautiful lady's eyebrow is something that had been traditionally done in Japanese and Chinese verses. Tamaki wrote, "Gabi is a metaphor of a beautiful eyebrow. They imagined a beautiful woman's eyebrow resembling the crescent moon on the top of Mt. Gabi" (Tamaki) as seen in Li Bai's famous poem called "the Song of the Moon on Mt. Gabi." This is Buson's poem:

\section{うすぎぬに君が朧や蛾眉の月 (Yosa Buson)}


Thin clothes, your translucent hazethe moon on Mt. Gabi

Oboro (haze) is a word that often used with hazy moonlit nights. Gabi is a word that describes the beautiful eyebrows of a woman as depicted in a Chinese poem about the moon on Mt. Gabi (Sichuan province). The moon setting on Mt. Gabi evokes a beautiful woman. Additionally, by using "haze" (oboro) in "your translucent haze" (kimi ga oboro $y a$ ), one can also imagine the body of a beautiful woman covered with clothing, which is translucent—and sexy—as spring haze. Tamaki writes that Buson "imagined a woman wearing a thin cloth, which is almost see-through, and blended with the sweet and sexy feeling of the hazy moon" (Tamaki). The mood is beautifully erotic, but what occupies the male protagonist's mind is not the beautiful landscape but the woman's pretty eyebrows as well as her body, which he wants to see through her thin clothes. Again, we see that Buson's haikai differs from Akiko's tanka in that Buson uses the moon as an elicitor of traditional poetic associations and juxtaposes them with unexpectedly funny, vulgar, and even erotic themes. The reader does not expect the poet to use the classically elegant combination of the hazy moon and the beautiful woman of Mt. Gabi to stimulate sexual arousal. Of course if readers lack knowledge about such classic associations, Buson's humor is less effective. On the other hand, when readers encounter Akiko's seasonal symbols, they work without any classical knowledge.

Akiko might have used conventionally associated ideas with these traditional topics, but she does not use these classical allusions like Buson and other haikai poets did to make fun of the tradition or to entertain. If readers perceive Buson's associations 
between classical waka canons and haikai's commoner aesthetics, they are funny.

Readers require knowledge of the convention, or "cultural memory" (Shirane 12) in order to fully enjoy Buson's haikai poems. Shirane wrote about the traditional associations of seasonal topics, "These seasonal topics and their associations, which formed the heart of the cultural landscape, provided the horizon of expectations against which haikai established its newness or implied difference" (Shirane 187). In other words, haikai poets still needed the canonized associations to work against. They used these traditional associations to make juxtapositions while Akiko sought their elimination and provided entirely new meanings for her symbols, which were based on personal feelings evoked by objects, not the longstanding traditional associations behind the objects.

\section{Symbolism and Japanese Poetry}

Japanese poets did not use the English term "symbolism," nor did they invent a Japanese equivalent before their country opened up to the West and before they absorbed its literature. Akiko applied this Western term to traditional waka practice. In Talks on Tanka, Akiko wrote, "We are not the ones that started symbolic poems," arguing that many poems from texts like Records of Ancient Matters (Kojiki), The Chronicles of Japan (Nihon Shoki), Collection of Ten Thousand Leaves (Man'yōshū), “could be categorized among two kinds of symbolic poems" (TAZ 20:100). So, there are two "kinds" of symbolic poems: the first kind have main and subordinate meanings; the second type have a comprehensive imaginary reality. Most of the Meiji-period poets just forgot this fact and placed undue emphasis on descriptive, explanatory, materialistic, 
objective verses and praise only these kinds" (TAZ 20:100). Makoto Ueda argues that Akiko made a bold step by applying the new modern and Western term — symbolism - to Japanese literary tradition because she opened the eyes of other poets in the modern era to new poetic possibilities, helping them realize that tanka could be a "daringly modern verse form" (Ueda 91). Akiko, in the middle of her career, believed that Western literature was more progressive than Japanese literature, and so Japanese poets should catch up to Western poetry. Literary critic Karatani Kōjin, in The Origins of Modern Japanese Literature, wrote that Meiji writers did not realize that in thinking this way they were creating an "inversion" (tentō) in their perception of their own literary traditions. In other words, they believed - If Karatani is correct — that literature followed a linear path of improvement. Ueda himself, as a conservative scholar of Japanese literature, could not evaluate Akiko's discovery other than "tanka could be a daringly modern verse form." In other words, Akiko and Ueda both were enraptured with the idea that tanka could become "symbolic" verse, but the practice, to which Akiko gave the Western name "symbolism," had existed in waka poetry for a very long time. By applying the Western term, both the Meiji poet and the postwar scholar were willfully forgetting the traditional features of Japanese literature all in the name of promoting "daring” Western(-like) progress. Although they were fascinated by the fact that there is a similarity between French symbolism and traditional waka, it does not mean they found something new in traditional Japanese poetry. The more remarkable achievement of Akiko-from the perspective of absorbing things which did not exist in Japanese poetry as an established concept—was her emphasis on one's self and subjectivity. 


\section{The Subjectivity and New Emotion}

Akiko often talks about "new emotion" in her writing. She talks about "new" and "modern" emotion in How to Compose Tanka, but her definitions were all somewhat ambiguous and not very easy to grasp. Morton clarified the definition of modern by citing Tekkan's declaration published in his magazine Morning Star (Myōjō), "We will publish poetry about our own egos (jiga no shi). This will not imitate the poetry of the past but will be our poetry, or rather, the poetry we have created individually" (17-18). "Ego" and "individual" are concepts derived from Western literature, and especially in Romanticism and Modernism, the existence of self, or individual (kojin) plays a pivotal role. Akiko indicates the important role of the self in their poetry's newness in a section called "The Songs of the Modern New Wave":

The modern new wave tanka, along with other kinds of modern art, were born from the hearts of adolescents in the Meiji and Taishō eras. People regained their energy from the stimuli of Western culture, and there was a mood in those eras that advocated avoiding obeying customs, that promoted the deep and intense sense of self, that instilled a desire for knowledge and seeking of freedom. We admired new things and we made an effort to live for our true selves. (TAZ 15:69)

We can observe a strong emphasis on an inner self, or interiority, from her phrases such as "deep and intense sense of self," and "desire for knowledge and seeking of freedom," and "one's true self." These kinds of assertions were what made the Myojjo poets new. Akiko often talks about "modern" poems by using "we" (watashitachi). She was arguing 
her theory as a representative of all the Myojjō romanticists or even all the poets of the Meiji-Taishō eras. Thus, "self" and "ego" are crucial to understanding what was new in her emotion.

Akiko talks about the form of tanka and how it can express "modern people's" complicated feelings. "Even though the form tanka is old, it can express the complicated emotions (fukuzatsu na kanjō) of people in modern days, and it can also give new stimulation and interest to readers. Tanka can play a new role well, and it has sufficient value and reasons for its existence" (TAZ 15:66). "Complicated" emotions of "modern" human beings were something new to Japanese poetry in the Meiji period. Karatani would argue that Akiko's "complicated emotions" of modern humans only seemed new to Japanese literature, because they were something derived from Western thought. It is not that Japanese people did not have complicated emotions before the Meiji period, but, as Karatani argues, Meiji Japanese fell into the trap of "inversion" because they suddenly discovered that their feelings could be "complicated" in the Western sense. Western literary conceptions of "literature" itself are what made Meiji era writers feel that their emotions rendered in their art are "complicated." Morton argues that Akiko's verse demonstrated the possibility of tanka as a tool to convey this complicated Western idea of interiority. “Akiko's verse, and this argument can be extended to Tekkan's verse too, played a pivotal role in demonstrating how new ideas from Western literature could be adapted to existing literary genre" (Morton 33) Morton differs significantly from Ueda in that Morton clearly mentions that this is an adaptation of the ideas already developed in Western literature. 
Morton writes "her poetry comprised the most significant and celebrated expression of romance and the female" (Morton 16). He also refers to the ideas of Watanabe Sumiko and writes, “The historical significance of Akiko's poetry is enormous, since it celebrated female subjectivity by using male sexuality as an instrument for the satisfaction of female eros" (Morton 16). This female subjectivity can be observed in her use of two new symbols, the spring moon and summer moon. By symbolizing young girl's romantic feelings with these moons, Akiko created a new female "subjectivity" in a way that was previously absent in Japanese poetry.

Because the idea of such a female self was new in Meiji Japan, Akiko needed a new term for it. She used jikkan — "true feelings". Jikkan was clearly the core of Akiko's aesthetics. In this sense, the subject of feeling, the female subject who expresses jikkan a new subjectivity - the sense of self that feels and expresses feelings. This new subjectivity has great significance in our understanding of how Akiko was changing not only tanka but literature as a whole. What is problematic is that the idea of jikkan itself was not a new thing in Japanese literature. Jikkan was not revolutionary. Akiko wrote that modern authors and poets should avoid ordinary ideas (heibon na chosō), which are fragments (danpen) of one's daily life, thoughts that anyone can come up with. She chose Ōtomo no Yakamochi’s (718-785) poem as an example of a poem does not have such ordinary ideas:

春の野に霞たなびきうらがなしこの夕光に鶯啼くも

(Ōtomo no Yakamochi, qtd. in TAZ 15:72) 
Mist trails

Across the fields of spring

Faintly sad

In the dusk

A warbler sings.

(Doe, 212)

"In the old days," Akiko writes (referring to the period of pre-ninth-century antiquity), "people used the word kanashi, like aware, to describe sadness, greatness, happiness, interest, all kinds of deeply felt emotions" (TAZ 15: 72). The fact that she used Yakamochi as a good example tells us that Akiko sees a continuity between the emotional life of premodern and modern Japanese. Akiko recognized that the expression of human emotion was essential to Japanese poetry from its very beginnings. This is also clearly expressed by Ki no Tsurayuki in the first text that evaluates the origins and purpose of poetry-the kana preface to Kokinshü:

The songs of Japan take the human heart (kokoro) as their seed and flourish as myriad leaves of words. As long as they are alive to this world, the cares and deeds of men and women are endless, so they speak of things they hear and see, giving words to the feelings in their hearts. Hearing the cries of bush warbler among the blossoms or the calls of the frog that lives in the waters, how can we doubt that every living creature sings its song?

(qtd. in Shirane, Japan and the Culture of the Four Seasons: Nature, Literature, and the Arts)

The seed of waka, or 31-syllable poetry, has to be in human hearts, and then it will become words. Kokoro means both "heart" and "feelings" in Japanese. Given this context and Akiko's previous use of Yakamochi's poem, we can understand how much she shares with both Ki no Tsurayuki's theory of waka and Yakamochi's practice. For Akiko, true feeling naturally drives her to write tanka; Akiko says flowers and the moon 
were not something just to observe, but they talk to her. In summer, they even sing a song of love. We can also see a similarity between "every living creature" (ikitoshi ikeru mono) and "everything" (banbutsu). Banbutsu expresses a modern-day animism—which derives from the true animistic spirit of traditional Japanese civilization. The considerable difference between Tsurayuki's Kokinshū preface and Akiko's summer can be found in how she asserts that they have "their own dignity and beauty" and "confidence." And yet, these are all related to the modern self. In other words, Akiko sang about her true emotions, and the existence of the subject of jikkan was there-the poet herself. Jikkan may have not been new, but this modern recognition of self and naming it jikkan was something new for this old form of 31-syllable verse.

\section{Romantic Sin}

Certainly, Akiko's sense of self is apparent in her romantic poems Akiko shined a spotlight on each individual's romantic feelings by singing of her own—or her female protagonists' - romantic passion and desire. In some of her tanka, one sees a pattern of the individual versus society, which takes the form of romance versus ethics. In a way, we can look at her romantic poems as her reaction against conventional morality, which was still dominant in the Meiji period. Indeed, she uses the word "sin" (tsumi) in her poems in Tangled Hair, and she used this word as rhetorical hyperbole. Moreover, even though she sometimes labeled her romantic feelings as "sin," her poetic personae praise and take pride in their sins. In a section called "Germination of the Self, Treason Against the Old Morality," Baba Akiko introduced the poem below, remarking that "Admiration 
of bewitching beauty expresses empathy for 'sin' against the old morality. It reveals Akiko's attitude of the being the antithesis of existing morality" (Baba 33).

歌にきけな誰れ野の花に紅き否むおもむきあるかな春罪持つ子 (Yosano Akiko)

Go ask among poems-

Who tells the wild flower

to spare its red?

That bewitching beauty!

Spring child clings to sin

(Beichman 168)

This idea of "sin," Baba argues, is the central theme of the entire Tangled Hair collection: "Akiko strayed close to the 'sin' of the old morality of Japan. This idea is one of the main themes of Tangled Hair. Akiko's approach to sin was very fresh, because it was a conscious awakening of the self. It also has the feeling of the modern West" (Baba 33). Thus, Akiko's Tangled Hair was innovative for its "consciousness" (ishiki), which contains "awakening of the self” (jiga no mezame) and has vibrant color and the fresh fragrance of the modern West. It is not hard to imagine that this fragrance of the West and the freshness of the sense of self attracted a certain number of people to new literature in Meiji Japan, including readers of Myōjō magazine. Indeed, her Tangled Hair has continued to attract people, even in the contemporary period (1945-) thanks to its celebration of the "sins" of modern Japanese women.

A Japanese poet and literary critic, Hinatsu Kōnosuke (1890-1971), presents the idea of Akiko's culmination of her sin with four important example poems (Hinatsu 305). More importantly for this thesis, all four poems are spring moon poems (introduced in the 
previous chapter). Hinatsu finds that Akiko's sins culminated under the spring moon. By extension, Akiko's “sins," which take place under the spring and summer moons, all exhibit a strong sense of self. "With her Romantic sensuality, Akiko liberated Japanese from their lack of sensitivity—or their rejection of sensitivity—imprisoned as they were in the Confucian model of the ideal life" (Hinatsu 312). Although Hinatsu does not use the actual word "self," it seems that Akiko needed a strong sense of "self" to liberate Japanese from their dreary insensitivity (fukan mukan) and thereby free the waka tradition. Baba describes this release of the self as "awakening of the self." Although these two critics describe this process somewhat differently, what they are talking about is "sin" perpetrated by an iconic modern girl of the Meiji Period.

\section{Poems of Sin Under the Summer Moon}

The figure of the Buddhist monk and the young woman in Tangled Hair stand at the center of a symbolic depiction of individuals rebelling against social norms. In her poetry, Akiko takes the stance of selfish love versus ethical living. We have seen how in some of these poems Buddhist icons, such as the monk figure, lotuses, and the moon serve Akiko's agenda of personal realization. Akiko's female persona bravely sings the joy of romantic attraction that either she feels for a Buddhist monk or that which he himself feels. In some poems, the words of romance and desire are not necessarily projected onto a monk. Nevertheless, it is notable that she expresses her romantic feelings while surrounded by the symbols of the ethical world. It is primarily because these symbols of morality are included in the poem that her romance becomes a "sin." 
Yet even when surrounded by these elements, by singing of love, Akiko beautifies and romanticizes her sinful feelings. She is not the villain, but the heroine of her poetic and Romantic visions.

Furthermore, the fact that summer is the season of passion for Akiko helps us to understand her young girls' rebellion against the old ethics, which takes place on summer moonlit evenings. Challenging social norms with her love clearly indicates Akiko's emphasis on the power of romantic feelings in people's hearts. Akiko praised the passion felt by each individual. In the summer poems we often see not only excellent examples of her representative theme of "sin," but also, we find her familiar figures of Buddhist monks. Although this specific poem does not have the moon in it, it expresses a strong opposition to ethical norms. In this famous poem, Akiko presents a female figure, who seduces a "preacher of the way" (michi o toku kimi), a Buddhist monk.

\section{やは肌のあつき血潮にふれも見でさびしからずや道を解く君 (Yosano Akiko)}

This hot tide of blood beneath soft skin and you don't

even brush it with a fingertip Aren't you lonely then you who preach the Way?

(Beichman 105)

This poem is famous for its direct expression of the woman tempting the monk with her beauty. Young monks in a training are forbidden to have heterosexual relations. The monk in this poem should be a paragon of abstinence. Akiko's bold expression of 
fascination with the poet's beautiful female body, as well as the poem's unethical intent, made this poem notorious in the literary world of the Meiji Period.

Scholars all acknowledge that this poem was very sensational at the time because of its bold expression. Shinma says, "Perhaps, it is the most famous poem in Tangled Hair" (Shinma 144). Beichman also notes “Akiko's famous poem begins with Yawahada no (soft skin) _" (Beichman 105). Itsumi says, "People recognize this poem as one representing Akiko herself." Although this poem is very famous and made her famous, Akiko hated this poem in her later career. As mentioned earlier, Akiko generally disliked most of her poems in Tangled Hair. Itsumi wrote, "In her later career, Akiko hated her poems in Tangled Hair. It is said that she even turned her face away when she asked for her autograph on shikishi [a square piece of thick paper for autograph].” She also mentioned that this is the poem Akiko hated the most, introducing the fact that Sato Haruo (1892-1964), a Japanese poet and novelist, evaluated this poem as "ideal and explicit" (kan'nen teki de rokotsu), which is why Akiko was so embarrassed by it (Itsumi 33). That, or Akiko came to dislike it so much for its overly explicit expression of "sin." Akiko herself wrote that "the preacher" in this poem is a monk with no personal identity, simply one of many "preachers in the world" (TAZ 15:29), scholars debate who was the model for the "preacher of the way" in this poem. Beichman took this poem as a poem about Tekkan. "With the boldness that poetic cover allowed, Akiko taunted Tekkan in the persona of the femme fatale — or shall we say a votary of the goddess of love" (Beichman 105). Shinma and Itsumi gave an alternative analysis of the model. They considered the possibilities of Tekkan and an old friend of Tekkan, who is also a 
poet and Buddhist monk, Kōno Tetsunan (1874-1940). Shinma says his identity remains "indefinite" (Shinma 144).

After giving her analysis, Itsumi provides an important key to read this poem: "The root of this poem is, as Akiko mentioned, a humanistic reaction against morality" (Itsumi 38). This "humanistic reaction" is not only the core of this particular poem, but something one can find in other poems that mention the moon, lotus flowers, and a Buddhist monk. The model for this preacher is uncertain. What is significant about this poem is Akiko's humanistic stance, in which love and romance challenge morality, in this case represented by Buddhism.

A young girl, who tempts Buddhist priests and who appropriates Buddhist icons for romantic purposes, also appears in Akiko's summer moon poems. In the poem below, Akiko presents two girls, Akiko and Yamakawa Tomiko (1879-1909), her best friend and future rival in her romance with Tekkan. The beauty of the two virgins tempts the lotus flower under the light of the moon. Here, the moon disturbs the white lotus by illuminating the romantic temptation of the two virgins.

たけの髪をとめ二人に月うすき今宵しら蓮色まどはずや (Yosano Akiko)

Two young women (hair as long as they are tall) under a pale moon Tonight, white lotus, will not their color lead you astray?

(Beichman 101) 
Beichman says, "they tempted the pure white lotus, a symbol of Buddhist purity and enlightenment" (Beichman 101). The two beautiful girls are tempting the pure white lotuses. Ever since the 800s, the word color (iro) also means erotic attraction. In this poem color is associated both with the girls and the flower. Their beauty will lead the white lotus to change its color. The pale moonlight enriches the mood of the beauty and the romantic feeling like in the other summer moon poems, so it helps the girls tempt their target. Itsumi's take on the poem is that the beauty of the girls has a dangerous influence on the pure lotus flowers, and the beautiful lotus flowers cannot stop competing with them in a beauty contest. She also says, "There is an emphasis on the beauty that is beyond the purity of the white lotuses, which is narcissism," Itsumi writes, "and she sings about the romance of youthful days enthusiastically, this is the most Tangled Hair-esque poem" (Itsumi 254). Indeed, as mentioned above, Akiko firmly said that summer makes a woman realize her own beauty and gives her confidence. Here, confidence has turned into narcissism. One can see the poet's strong belief in her own beauty; in other words, a strong belief in herself, which challenges ethical and ascetic monks (symbolized by the lotuses).

Akiko's romantic feeling towards preachers or monks, which is her "humanistic reaction" against morality, is one of her signature expressions. Baba Akiko talks about unconstrained love in the poems of Tangled Hair and says, "In the passion of youth, which keeps overflowing, Akiko realized in nature that there is something way beyond the ethics in the world" (Baba 41). What beautifies Akiko's rebellion against the old morality is the moon. The moon works as a symbol of Buddhist enlightenment, and at 
the same time, as a symbol of her romantic sin. Akiko adores the solemn image of a monk in another summer moon poem.

旅のやど水に端居の僧の君をいみじと泣きぬ夏の夜の月 (Yosano Akiko)

An inn for travelers-

There you sat by the water's edge

O Priest, so pure and

so forbidding that I wept

beneath the summer moon

(Beichman 212)

Beichman explains that the girl "is moved to tears by a young priest staying at the same inn, but she is too much in awe to approach him" (Beichman 212). She cannot approach the priest resting on a veranda by the edge of the water, perhaps a river or a lake. The thing preventing her from approaching him is the aura of the monk. The summer moon is lighting up his beauty, which expands the admiration in the girl's mind. The moon is controlling the mood of Akiko's poetic persona in the poem. Akiko chose the moon to play this pivotal role. In other words, Akiko used the moon to illustrate the mood, emotions, and even the inner self, which is externalized in the shape of the landscape. Also, the line "so forbidding that I wept" shows us a strong sense of self. We can see that Akiko's persona is moved by the noble figure of the monk. One can find that other lines are all describing the landscape, and "so forbidding that I wept" is the only line that focuses on her inner self. Also, the words "forbidding" (imiji), and "wept" (nakanu) have a strong sense of emotion in them. The 4th line makes an abrupt transition between the landscape and herself. This contrast between the coolness of the moonlit summer night 
by the water and the girl's passionate, intense emotion gives us a strong impression of the existence of her poetic self in the poem.

In yet another poem, Akiko presents a strong poetic self. It too contains all the icons of Buddhism mentioned above: the Buddhist monk, lotus flowers, and the summer moon.

男きよし載するに僧のうらわかき月にくらしの蓮の花船 (Yosano Akiko)

The handsome oarsman carrying a priest how youthful on the lotus viewing boat you hateful moon

Now two male characters - the oarsman and a monk - are beautiful. In the girl's eyes, these two men are too beautiful to be true. Here she ironically curses (nikurashi) the moon, which shines on and accentuates the beauty of these handsome men, making her desire them more. The moon here is working as something that intensifies the beauty of the men. It will not let her take her eyes off them.

The reason why she curses the moon is not easy to determine. In fact, scholars have different opinions on this matter. Itsumi once wrote that the girl curses the moon because it is intensifying the beauty of these two men (Itsumi 50). Konno's interpretation is similar to this (Konno). However, Itsumi changed her opinion later. In New Annotations of Tangled Hair (Shin Midaregami zenshaku,1996) she said, "youthful" (urawakaki) works for both the priest and the moon. Urawakaki tsuki (young moon) means the new moon (shingetsu), which normally gives a weaker light. Thus, the female 
persona curses the moon since she cannot see enough of these two beautiful men because the night is nearly moonless (161-162).

Moreover, there is another possibility considering the role of the moon and the priest in Tangled Hair. As we have seen, Akiko challenges traditional morality with her romantic sins, and the moon is conventionally used as a symbol of Buddhism and purity. Hence the purity and ethics symbolized by the moon are something preventing her from directly expressing romantic feelings. Here she uses the word "pure" (kiyoshi) to describe the man on the boat. For her, purity is embodied by a handsome man not the moon. The moon's religious ethics and purity obstruct her "pure" romantic feelings and cast them as sin. This poem successfully captured the poet's complicated romancerelated sense of self. However, whichever interpretation we take from these three alternatives - it is also possible that all of them are correct. In this poem we can see a number of important elements argued within this thesis: Akiko's inner landscape illuminated by the romantic moon; the structure of romantic sin versus ethics; as well as the existence of the self, which even curses the moon.

\section{Realistic Moons and Romantic Moons}

In the early Meiji period, realism was an important current in the world of Japanese literature. Realism and Romanticism were the two major styles of literature around this period, beginning roughly from the 1880s with Tsubouchi Shōyō Essence of the Novel (Shōsetsu shinzui) through the rise of the Naturalist movement after 1905 (Tayama Katai and Shimazaki Tōson being notable examples). Each group formed 
communities of writers and published magazines. These two groups were very vibrant in the literary world. Masaoka Shiki, who is known as a leading poet of the current of Realism, had developed his signature style, known as shasei, which means sketching from nature. He inspired many followers in the field of haiku poetry.

Donald Keene introduced Shiki's shasei style in the introduction to his book about the poet's life, The Winter Sun Shines In (2013). Keene mentioned that Shiki's shasei is influenced by a painter, Nakamura Fusetsu (1866-1943), "who, after studying European paintings, had reached the conclusion that art of any kind must faithfully reflect whatever it portrays.”

This variety of realism contrasted markedly with the ideals of Japanese painters of the time, who made it their practice to imitate closely the works of their teachers, painting the same "poetic" landscapes, not feeling any need to discover fresh scenes or viewpoints of their own. The paintings they produced - mountains in the mist, men crossing flimsy bridges over gorges, and so on - were pleasing to the eye but lacked both originality and fidelity to any actual landscape. During the discussions between Shiki and Fusetsu that began soon after they met in 1895, Shiki at first defended traditional Japanese painting, preferring its artistry to European realism; but Fusetsu eventually convinced Shiki that shasei was essential not only in painting but in the haiku. Once convinced, Shiki made up his mind that his haiku would treat the experiences of daily life, and he turned his back on cherry blossoms and colored autumn leaves, the hackneyed subjects of Japanese poetry. He would write instead about what he himself had seen or felt, regardless of whether or not it was conventionally beautiful. (Keene 3)

For their mutual departures from conventional beauty, and their mutual desires to find their own way to capture beauty, Shiki and Akiko seem somewhat similar in terms of a poetic starting point. However, Akiko chose a romantic approach and Shiki chose realism. Akiko nevertheless, felt compelled to address literary realism. Ueda explains 
how Akiko felt about shasei and how her poems are different from Shiki's school of poetry.

She distinguished between the truth of art and that of science identifying the latter as factual truth lying in external reality, the former as subjective truth hidden in the individual human heart. To her way of thinking, a poem that sketches nature merely copies fact, not truth. (Ueda 57)

The big difference here is that Shiki was trying to get closer to real, natural beauty while Akiko was trying to create landscapes which embodied her true feelings.

In an article entitled "The Moon for a Haiku Contest" ("Kuawase no tsuki") published in his school's own magazine, The Cuckoo (Hototogisu), Shiki explains how he depicted the moon in his poetry in his shasei style. He recorded his path of thoughts when he was composing a poem about the moon for a haiku party. Shiki talks about the process of writing and discarding poems of the moon. From descriptions in the article, we can see how Shiki generates shasei style haiku for one topic, which this time is the moon. The article reveals the characteristic differences between the two poets, but it also shows that both of them were depicting landscapes from their inner visions. In other words, they both use the same source, which is their inner world and fragments of their memories of experiences, but the directions and the results are quite different. Shiki tried to find a realistic landscape from his memory while Akiko was trying to illustrate her emotion by using landscapes.

Haiku contests (kuawase) are customary gatherings for haiku poetry, in which poets are split into two groups and compete with each other with their poems. The theme (dai) can be given before the participants assemble. Shiki was given the moon as a theme 
for an upcoming gathering. "I decided to make it a shasei poem as much as possible" (Masaoka), he writes, explaining his way of composing. From this comment, it is clear that this is not just an article about a poem, but this is the record of Shiki's thought process when composing a shasei-style haiku.

Before talking about his actual process of composing, Shiki briefly talks about the situation: "It seems like I have a fever tonight. It is hard to breathe. So I decide to lay down and compose a poem for the haiku party. Then I start to think about a moon poem on my bed as I'm putting a thermometer under my arm" (Masaoka). And then, he started travelling in his mind, thinking about different kinds of landscapes to find an appropriate landscape for his shasei-style haiku. "The first scene that comes up in my mind is a moonlit path along a forest, the other side of which is an open field, and I am walking there. Perhaps I came up with this boring landscape since I am just focusing on being realistic" (Masaoka). This "first scene that comes up in my mind" clearly tells us that Shiki took an imaginative journey, following his inner eye to find "realistic" landscapes to serve his shasei purpose.

Like a painter who travels around with a sketchbook to find the best landscape to illustrate, Shiki wanders through his inner vision, relying on his notes, memories, and imagination.

However, the picture can deviate far from Realism when you try to depict wider landscapes, so I try to write more details. I come up with an image like the dappled moonlight you can see in between the leaves of a tree. And the poet is stepping on the shadows in the forest, as he is watching the dappled moonlight on his right. No matter how long he watches the moonlight, it's not going to shine on his face directly. Well, this experience is a too long to be a haiku. So I go back home. 
The text above tells us that Shiki was trying to find the best situation for shasei-style haiku. To do so, he travels in the imaginary world of his mind and looks for an ideal landscape for his moon poem. During this journey, he keeps composing and discarding moon poems. The figure traveling in his inner world is Shiki, a tuberculosis-stricken invalid, traveling around in his imagined world on his imagined healthy feet. But the big difference is that he can control the landscape because it is in his own inner world. In other words, he finds an ideal landscape for his shasei poem in a world he can control.

The quote below tells us that Shiki actually imagined his ideal landscape, but it was more like a scene that Romantic poets would illustrate. However, Shiki of course discards this landscape because it is not appropriate for shasei and continues his journey.

I imagine the wide mouth of a river, entering the ocean. It makes me think of the Yangtze River, even though I have never seen it. On that broad river, there is a boat floating. Of course, since it is a moonlit night, the currents are sparkling as they reflect the moonlight. It's very bright, like daytime. I can even see a boat far away, and I come up with the idea that the boat goes farther away and gradually fades out, but I can't make a poem out of it. The boat has not faded away yet, and it is like floating in the air. It appears almost as though it is a boat of heaven. But the illustration of an ideal image is taboo in my Realism, so I try to forget it. But I can't get rid of that image from my head.

(Masaoka)

"I try to forget it." indicates that Shiki denied the idea, even though it moved his heart.

Even though he saw a beautiful image of a "boat of heaven," in the same inner, imaginary world, in which he is trying to find a good topic for a shasei style poem, he abandoned that beautiful image because this "ideal image" is "taboo" for shasei. What Shiki found here is similar to jikkan, since, although it is a vision, he is moved by what he sees in his 
imagination - "almost like a boat of heaven." It was such a powerful image he could not forget it. The movement of his feelings (jikkan) created a powerful image for him, but importantly, he rejected his feelings for the purpose of poetic composition.

What he was doing here is neither illustrating a real landscape, nor symbolizing his true feelings, but trying to get closer to something real. Karatani gave careful consideration to "real" landscapes in Japanese literature. Quoting Kobayashi Hideo (1902-1983), Karatani describes how the discovery that Realists writers made that was similar to Shiki's discovery: "What we call 'reality' is already nothing more than an internal landscape" (Karatani 34). This too is what Shiki then discovered in his extreme pursuit of Western realism.

After composing and discarding eight poems for his assignment, Shiki finally decided on this poem:

見送るや酔のさめたる舟の月 (Masaoka)

Seeing him off, sobered up

A boat in the moonlight

Here is his description of the process of getting to this poem.

I think about a scene in which man and woman are saying good-bye. The woman stands along with the man. She keeps silent and doesn't say any words. Thus, there are complicated emotions in her mind. The man also looks depressed and is standing there. Without being noticed by anybody, he firmly grabs her hand. Then, he gets on a boat. The woman does not even move. I come up with this scenery. And I compose "At a pier / loathing to part / a wife and a husband" (栈 橋に別れを惜む夫婦かな) but there is no moon in it. Then I imagine my hometown, Mitsu, and think about a scene of departing on the shoreline, but I 
give it up. Eventually, I compose "Seeing him off / sobered up / A boat in the moonlight." It is truly a boring poem, but there are no major problems, so I decide to keep it. (Masaoka)

From this critique of the process of composition, one can imagine the emotions of Shiki's poetic persona. However, in the poem itself the emotions are not described in a direct manner like those seen in Akiko's poem of the lotus viewing boat. Shiki is illustrating the most basic facts and he lets readers imagine the poetic persona's emotion, whereas we see the expression of subjective appreciation of things, such as "beautiful" (kiyoshi) and "youthful" (urawakaki) in Akiko’s poems. However, the most striking use of emotion in Akiko's poem can be seen in "you hateful moon" (tsuki nikurashi) while there is no such expression in Shiki's haiku. Although one can vaguely sense emotions from Shiki's haiku, there is no direct expression of emotion like in Akiko's tanka.

Although scholars of Japanese literature, like Keene, often declare that Shiki's shasei is poetry of realism, Kobayashi Hideo maintains that "realism was not 'objective' but tried to reach 'objectivity,' which is an act of destruction of the core of your consciousness" (Karatani [1980] 41). What Shiki was doing in his inner world was trying to achieve shasei, which was somewhat similar to Kobayashi's realists trying to achieve their "objectivity." To achieve shasei, Shiki was wandering around his inner landscape and denying the imaginary and sometime fantastic visions he saw. Such a visionary approach to poetry, for Realists, is exactly what a poet should avoid, but for Akiko, it was the supreme form of jikkan.

Fake jikkan believers, who do not know that fantasies are the supreme figure of one's jikkan, do not even experience fantasies and confuse them with fake and 
false feelings — which are fake visions (kūso) — and try to contrast the real with jikkan. And then, they reject our poems as poems of fake visions without any fair criticism. (TAZ 15:91)

This statement is Akiko's response to the attack from her Realist critics. She attacks their descriptive (kijutsuteki) poems, writing, "We would like to hear about the unique movement of the poet's heart stimulated by nature. However, they are just trying to make copies of the surface of nature, which everyone can see, with their descriptive poems." Akiko continues, "If the content of the poem does not express the poet's unique feelings, no matter what kind of words they have, they are just empty and ordinary. Is it even worth calling them poems?" (TAZ 20:93). This very strong, even aggressive statement is her reaction to the attack from the Realists, although not necessarily by Shiki himself. Hinatsu explains that Shiki himself analyzed Myōjō Romantics thoroughly and rationally criticized Tekkan; however, "Realists and their imitators fell into emotional arguments, expressing aversion as if eating food they detest, and they devolved into blind, illogical argumentation" (Hinatsu 310). Akiko's strong reaction was perhaps, against those people with their "blind illogic[al]" thinking. She listed poets that influenced and inspired her at the beginning of How to Compose Tanka, and she included Shiki's name. She wrote, "I learned a lot from them" (TAZ 15:21).

However, she also criticized the style of shasei in a section called "There is No Such Thing Called Shasei or Jokei in Poetry." "Some poets think that there is a kind of poetry called 'shasei' or 'jokei' [description of scenery], and it should be distinguished from ‘jojō’ (lyrics). But I don’t think so. I believe all verses should be lyric poems” (TAZ 15:36). She thinks that even if a poem contains images of mountains or fruits or flowers, 
they are expressions of poets' jikkan but not shasei or copies of the real landscape. And then, she firmly denies shasei:

There is a difference between jikkan stimulated by humans and jikkan stimulated by objects and nature. Poets have to express the jikkan that occurs in their inner selves. Therefore, all poems are lyric poems (jojōshi). If there are special kinds of poetry such as shasei or jokei, poets have to illustrate objects and nature in front of them like taking a photograph. They are not allowed to compose a poem afterward. But a poem does not function as a photograph. First of all, this is not the purpose of poetry. If one's jikkan is still fresh, and if one can keep it deep inside of their consciousness, a poet can still say that it is a jikkan of today, even if it is jikkan stimulated by an object, natural image, or a human being from ten years ago. (TAZ 15:36)

Shiki was, first of all, not composing haiku about scenes immediately in front of him or sketching from nature, at least for the moon poems he created for the haiku contest. However, what is remarkable about this statement is that Akiko says copying something like a photograph is not the purpose of poems in the first place. The emotions of the poet are the origin of poems. Even if Realists are illustrating from a still life or nature, the poet's feeling should be created by these objects. In other words, there should be emotions and a sense of self that is feeling these emotions. Therefore, all poems are lyric poems, according to Akiko.

The crucial difference between Akiko and Shiki-regarding the moon poems in Tangled Hair and "Kuawase no Tsuki" - is that objects and landscapes are representative of emotions and self for Akiko. In contrast, Shiki was trying to depict reality. The moon in Tangled Hair and "Kuawase no tsuki" reveals this difference between the two poets. They both create poems depicting landscapes from their inner visions, but Akiko 
advocates using visions and fantasies as the best way to externalize jikkan and makes landscapes express her emotions. She does not hesitate to depict fantastic landscapes even as Shiki denies this practice. Shiki's "The Moon for a Haiku Contest" demonstrates that his creative process began with his inner visions, but he rejected them in his attempt to get closer to the real world. These two poets departed from the conventional beauty of classical Japanese poetry and the landscapes based on them. However, their artistic work is notably different. Shiki was trying to create more objective and realistic landscapes than the ones drawn by predecessors, while Akiko expressed modern people's complicated emotions using traditional imagery. 


\section{Conclusion}

When you criticize my poetry, please do not set your standard (hyōjun) as Japanese poetry, but please consider my poem with the modern (gendai no), global (sekai kyōtsū no) standard. (Yosano, The Sun and Roses)

This is a quote from the self-preface of Yosano Akiko's 17th collection of poetry called The Sun and Roses (Taiyo to bara 1921). Before this sentence, she asked her readers to "find value in her unique movement of the heart" (kandō). Quoting Tolstoy, she mentioned that her ideal is "getting closer to this kind of art, even by one step or two steps" (Yosano). Akiko apparently was making an effort to have her poetry catch up with the greatest works of Western literature.

Akiko's yearning for a "global" literary standard is precisely the kind of (Western) ethnocentric view that Karatani Kōjin saw as an endemic problem in modern Japanese literature. She quotes Tolstoy and believes that she is "getting closer" to his level of "global" art. Karatani believed that Natsume Sōseki (1867-1916) was one of the few Meiji writers aware of the danger of this kind of thinking in Meiji literature. "Since no one can logically maintain that there is only a single path a developing literature can follow," Sōseki wrote, "or a single point it should attain, it is rush to assert that the trends of Western literature today will be those of Japanese literature tomorrow." Karatani mentioned that this quote shows Sōseki's argument against the "hidden ethnocentrism of the "history," or "the view that history is continuous and inevitable." One powerful example for Karatani is how Sōseki saw Romanticism and Realism as merely two 
"elements" of a similar ideological trap, even though they seem different, they are merely "products of history," that "appeared in historical sequence" (Karatani 13-15). The faith in historical development, or evolution, is what is concealed in the ideological assumptions by Meiji writers about the proper ordering of these two movements. Soseki, Karatani asserts, was uncomfortable with the historical thinking associated with such a view of literature. Karatani stresses that other Meiji writers, even Tsubouchi Shōyō, excelled "in daring not to accept a Western view of 'literary history,' making him similar to Sōseki, who conceived of his own theory of literature" (149). For better or worse, Akiko goes unmentioned in this connection in Karatani's Origins of Modern Japanese Literature.

Even though Akiko emphasizes the "new feelings" (atarashii kanjō) of her tanka, the staple of her theory of poetry, which is jikkan, was not completely new from the perspective of traditional waka practice. As discussed earlier, that kind of language is in the Kokinsh $\bar{u}$ preface, written in the early tenth century. However, subjectivity and interiority were something new to Akiko's poetry, as well in every literary genre in the Meiji Period. Karatani argues that as Japanese embraced Western thought, Meiji writers under the spell of Western literature essentially sold out—or willfully forgot—-their past to establish a new Japanese identity that was rooted in the "inner voice" or "interiority" (naimen), which was crucial in a new ontological configuration that emphasized depth of feelings. For such writers, the more feeling (naimen) the character had, the more real he or she was. For premodern Japanese, "it is unlikely that they were not feeling things deeply. If, in spite this, we say there is no depth to their literature," or if we strain to see such "depth" in their literature, we make a fundamental mistake. "The questions we must 
ask concern what 'depth' is and by what means it was produced" (136). So the problem of Akiko's "new-feeling” poetry must be located in how her poetic personae are configured with "depth" against their landscapes — lit with spring or summer moons.

Landscape is a critical aspect of Karatani's critique of modern ideological constructs that essentially hidden, not illuminated, truth for Meiji Japanese writers. Karatani argues that "rather than existing prior to landscape, subject and object emerge from within it" (Karatani 34). The discovery of interiority started by drawing a line separating self from other objects, and landscape was the a priori thing to be "discovered" against the foregrounded self. In other words, once people discovered landscapes - as something exterior to themselves - then they found their interiority. For Karatani, this "discovery" is a fundamental mistake, or inversion (tentō), that Japanese writers - and Japanese literary historians - made and continued to make in the postwar period. This separation of self from landscape was what waka did not have until the modern period. In The History of Study of Waka (Nihon Kagakushi, 1910) a poet, a scholar of Japanese literature, Sasaki Nobutsuna (1872-1963) mentioned that Ki no Tsurayuki introduced the thought of "the heart" (kokoro) working together with "words" (kotoba) (17). As we can see, since Kokinsh $\bar{u}$, the heart was not exterior to or working against the landscape, but kokoro should be in harmony with kotaba. There was not a structure of self-pitted against words or pitted against external objects yet. To see the emergence of the sense of self, we have to wait until the modern period. With help from the West, Japanese writers and artists discovered how to pit the self against the landscape to deepen the sense of self.

The tension between the subjective self and external objects was a significant theme of modern Japanese literature. This theme of subjectivity and objectivity was not 
simple. It is not simple like just setting a border line between the two ideas and saying one is Romanticism and the other is Realism. As Sōseki said, Romanticism and Realism are just "two elements," because they are just two major currents with more similarities than differences between them. Karatani writes, "genuine realism had to be based on the preeminence of the inner self" (Karatani 30). To elaborate on this idea, he first explained that Realists had to discover "landscapes from which we had become alienated" (Karatani 29). In other words, "a relentless defamiliarization of the familiar" was the essence of Realism. By creating new landscapes, they are "bring[ing] into existence landscapes which, although they had always been there, had never been seen" (Karatani 29). Karatani writes that even for the shasei Realists Shiki and his disciple, Takahama Kyoshi (1874-1959), "their practices established a basis for interiority" (Karatani 65). In other words, if the existence of the self and the boundary separating the self from external objects can be observed even in the poetry of Realists, then we can see that it is an essential element to analyze any Meiji literature, especially that of the Romantics.

According to Karatani, before they discovered landscape under the influence of the West, what Japanese were illustrating were the ideas involved with landscapes. Like for example, in sansuiga (mountain-water pictures) what people see (and expect) is not the actual nature but the classic ideas behind the scenery. If this is true, what Akiko did with her summer moon and spring moon is somewhat similar to the traditional practice of waka. She used the moons in summer and spring as a symbol of her feelings. Temperature, flowers, birds, and weather helped her to create her feeling of seasons. However, what she did differently from sansuiga artists and premodern waka poets is this: Akiko's summer moon poems and spring moon poems are not the actual landscapes 
of summer or spring evenings, but her ideals of summer and spring nights. To create modern "depth" and foreground her inner self (naimen), she applied her own ideas (kan'nen) on top of the classic moon landscapes of Japanese poetry. In a Karatanian sense, Akiko “discovered” herself (her foreground) against her new landscapes of traditional Japanese poetry.

Romanticism and Realism, for example, Akiko and Shiki in their respective poetry, both sought a departure from the traditional associations between objects and ideas. Akiko wanted to express new feelings, and Shiki tried to poetically capture new landscapes, which had not been depicted in Japanese poetry before the Meiji period. On the surface these two endeavors might look very different from each other, but in a broader sense, what they both drew similar a boundary line separating the inner self from external objects. Shiki was making shasei style poems with "the preeminence of the inner self." Likewise, Akiko created "landscapes from which we had become alienated" (Karatani 29) in order to foreground her interiority. Akiko created the same inversion (tentō) as Realists, like Shiki did. What Akiko illustrated as landscapes are more like mindscapes, which were not real. Her mindscapes were hers. She was no longer beholden to tradition because she modified traditional landscapes with her own feelings_ — and Japanese literary tradition.

However, she still looks at objects as objects; in other words, something different from the self. Other writers too in the Meiji period discovered the landscape as an external object. She mentions that poets should "arouse sympathy with nature, and feel a sense of unity with nature" (TAZ 20:99). This quote clearly explains that Akiko had a sense of self and looked at nature as an external object, which should be separated from 
the inner self. Yet ultimately, she was using these external objects—-here moonlit landscapes in spring and summer - as a means to depict her mindscapes. They foreground the Western sense of self that Akiko needed to make "global" poetry.

Borrowing Kobayashi Hideo's words, Shiki's effort can be described as an "attempts to reach" the object (Karatani 34). If this is true, then we can describe Akiko's actions as the effort to reach her interiority—as mindscapes— by using the external objects, including her spring and summer moons. Both Akiko's and Shiki's poetry contain the sense and existence of the self. Their recognition of the sense of self and external landscape is precisely what differentiates their verses from premodern waka and situates their poems among works of modern Japanese literature. If individuality was highly prized by prose writers and poets of the Meiji Period, it could only be achieved by superimposing the Western-derived notion of self onto premodern poetic associations, like the landscape. And, as this thesis has consistently demonstrated, to be a modern poet in the Meiji period, Akiko had to make the moon hers. 


\section{Reference}

Baba Akiko. Yosano Akiko no shūka. Tanka Shinbunsha, 1981.

Beichman, Janine. Embracing the Firebird: Yosano Akiko and the Birth of the Female Voice in Modern Japanese Poetry. University of Hawaii Press, 2002.

Cranston, Edwin A. Translation. The Izumi Shikibu Diary: A Romance of the Heian Court. By Izumi Shikibu. Harvard University Press, 1969.

Doe, Paula. A Warbler's Song in the Dusk: The Life and Work of Ōtomo Yakamochi (718785). University of California Press, 1982.

Goldstein, Sanford and Shinoda, Seishi. Translation. Tangled Hair: Selected Tanka from Midaregami. by Yosano Akiko. C.E. Tuttle Co., 1987.

Haga Tōru. Midaregami no keifu. Kōdansha, 1988.

Hinatsu Kōnosuke. Hinatsu Kōnosuke zenshū vol.5 Sakkaron. Kawaide Shobō Shinsha, 1991.

Hiraide Shū. Shinpa waka hyōron. Meikōshoin, 1901.

Holt, Jon. "Chocolate Revolutionary: Tawara Machi's Rule-Breaking Tanka Verses." Japanese Language and Literature, vol. 52, no. 2, 2018, pp. 341-372. JSTOR, www.jstor.org/stable/26739682. Accessed 21 May 2020.

Itsumi Kumi. Midaregami zenshaku. Ōfūsha, 1978.

Itsumi Kumi. Shin Midaregami zenshaku. Yagishoten, 1996.

Karatani Kōjin. Nihon kindai bungaku no kigen. Iwanami Shoten, 1980. 
Karatani Kōjin. Origins of Modern Japanese Literature. Translated by Brett de Barry. Duke University Press, 1993.

Kanetsune Kiyosa and Miyauchi Tamako. Yosano Akiko. Mikasa Shobō, 1948

Keene, Donald. The Winter Sun Shines in: a Life of Masaoka Shiki. Columbia University Press, 2013.

Kokin wakashū. Edited, with notes, by Takada Hirohiko. Kindle ed., Kadokawa, 2014.

Konno Sumi. Translation and Annotation. Midaregami anime kabā ban. by Yosano Akiko. Kindle ed., Kadokawa Shoten, 2017.

McCullough, Helen Craig. Translation. Tales of Ise: Lyrical Episodes from TenthCentury Japan. Tokyo University Press, 1978.

Morton, Leith. Modernism in Practice: an Introduction to Postwar Japanese Poetry. University of Hawaii Press, 2004.

Masaoka Shiki. "Kuawase no Tsuki” Aozora bunko, 1989, www.aozora.gr.jp/cards/000305/files/50381_39088.html. Accessed 19 May 2020.

Mostow, Joshua S. Pictures of the Heart: the Hyakunin Isshu in Word and Image. University of Hawaii Press, 1996.

Nagata Kazuhiro. Kindai shūka. Iwanami Shoten, 2013.

Sasaki Nobutsuna. Nihonkagakushi. Hakubunkan, 1910.

Shirane, Haruo. Japan and the Culture of the Four Seasons: Nature, Literature, and the Arts. Kindle ed., Columbia University Press, 2012.

Shirane, Haruo. Traces of Dreams: Landscape, Cultural Memory, and the Poetry of Bashō. Stanford University Press, 1998. 
Shirane, Haruo. Traditional Japanese Literature: An Anthology, Beginnings to 1600. Columbia University Press, 2007.

Shin kokin wakashū jō. Edited, with notes, by Kubota Jun. Kindle ed., Kadokawa, 2014.

Shinma Shin'ichi. Yosano Akiko. Ōfūsha, 1981.

Shimazaki Tōson. Nihon kindai bungaku taikei 15: Tōson shishū. Kadokawa shoten, 1971.

Strong, Sarah M. "Passion and Patience: Aspects of Feminine Poetic Heritage in Yosano Akiko's Midaregami and Tawara Machi's Sarada Kinenbi." The Journal of the Association of Teachers of Japanese. 25:2 (1991). 177-194.

Takahashi Junko. Tsuki no namae. DECO, 2012.

Ueda, Makoto. Modern Japanese Poets and the Nature of Literature. Stanford University Press, 1983.

Yosa Buson. Buson kushū. Kindle ed., Kadokawa, 2014

Yosano Akiko. Midaregami. Kindle ed., Aozora Bunko, 1901.

Yosano Akiko. Taiyō to bara. 1921. In Yosano Akiko zenshū: 138 Works in 1 Book. Yosano Akiko Zenshu Shuppan Īnkai. Kindle ed., 2015

Yosano Tekkan and Yosano Akiko. Tekkan Akiko Zenshü. Vols. 13, 15, 20, and 21. Bensei Shuppan, 2004-2006.

Yusa Michiko. "Dōgen and the Feminine Presence: Taking a Fresh Look into His Sermons and Other Writings." Religions 9.8 (2018): 232. Crossref. Web. 